\title{
Skocznie x3
}

\section{Ski jumping hills x3}

\section{Streszczenie}

Skocznie narciarskie są kosztownymi obiektami przeznaczonymi dla niewielkiej liczby odbiorców, których zmagania oglądają tysiące widzów. Pod koniec XX wieku, zauważono, że skocznie zdominowała funkcja. Pierwszym obiektem, który wyłamał się z tej konwencji był skocznia Bergisel. Zupełnie nowa estetyka, wprowadzenie widzów na szczyt skoczni poza zawodami, by mogli poczuć się jak skoczkowie, różnorodność funkcji towarzyszących sprawia, że ten przykład staje się modelowym rozwiązaniem dla kolejnych realizacji. W miarę dostosowywania tych budowli do zmieniających się wymogów bezpieczeństwa narzuconych przez FIS oraz zwiększania możliwych odległości lotu skoczków, przebudowywano kolejne skocznie. Jednymi z kolejnych, niezwykle udanych rozwiązań są skocznia olimpijska w Garmisch-Partenkirchen oraz Holmenkollenbakken w Oslo. W obu przypadkach, modernizacje zostały wyłonione na podstawie ogłoszonych konkursów architektonicznych. Czy skocznie stały się bezpieczniejsze dla skoczków, jak zmieniły się rozwiązania technologiczne i jak bardzo są przyjazne środowisku? W jaki sposób wprowadzono rozwiązania smart do użytkowania tych budowli? Jak zmieniła się estetyka tych konstrukcji? Analizując trzy wymienione przykłady obiektów sportowych, autor poszukuje odpowiedzi na powyżej zadane pytania.

\begin{abstract}
Ski jumping hills are costly structures meant for a small group, whose struggles are being watched by thousands of spectators. Towards the end of the twentieth century it was observed that ski jumping hills had been dominated by their function. The first structure that broke away from this convention was the Bergisel ski jumping hill. A completely new aesthetic, introducing spectators to the top of the ski jumping hill outside of competitions so that they could feel like the ski jumpers themselves, as well as a variety of accompanying functions, made this example a model solution for successive projects. As these structures are being adapted to the changing security and safety needs imposed by the FIS, as well as the increasing distances that ski jumpers can travel in the air, additional ski jumping hills were being remodelled. Some of the later, extraordinarily successful solutions include the Olympic ski jumping hill in Garmisch-Partenkirchen and Holmenkollenbakken in Oslo. In both cases modernisations were selected on the basis of architectural competitions. Have ski jumping hills become safe for jumpers? How have technological solutions changed and how friendly are they to the environment? In what manner have smart solutions been introduced into the use of these structures? How has the aesthetic of these structures changed? By analysing three of the aforementioned examples of sports facilities, the author searches for the answer to the questions above.
\end{abstract}

Słowa kluczowe: Oslo, Innsbruck, Garmisch-Partenkirchen, architektura sportowa, skocznia narciarska Keywords: Oslo, Innsbruck, Garmisch-Partenkirchen, sports architecture, ski jumping hills

\section{Wstęp}

Skocznie narciarskie. Miejsca wyjątkowe. Są to kosztowne obiekty, z których korzysta garstka użytkowników. Jednak tę niewielką ilość zawodników obserwuje zwykle kilkanaście tysięcy widzów. Do końca XX wieku, elementem dominującym w realizacji tych obiektów była funkcja. Przełom wieków to zwrot w projektowaniu skoczni. Zaczyna liczyć się również forma, energooszczędność, przyjazne środowisku rozwiązania technologiczne oraz różnorodność funkcjonalna. Wieże skoczni nie służą już skoczkom a stają się punktami widokowymi. Na górze można również dobrze zjeść. Jednym z pierwszych przykładów nowego myślenia jest skocznia w Bergisel w Innsbrucku. W miarę dostosowywania tych budowli do zmieniających się wymogów bezpieczeństwa narzuconych przez FIS oraz zwiększania możliwych odległości lotu skoczków, przebudowywano kolejne skocznie. Jednymi z najpiękniejszych przykładów oprócz skoczni Bergisel stały się skocznia olimpijska w Garmisch-Partenkirchen oraz Holmenkollenbakken w Oslo. W obu przypadkach, modernizacje zostały wyłonione na podstawie ogłoszonych konkursów architektonicznych. Czy skocznie stały się bezpieczniejsze dla skoczków, jak zmieniły się rozwiązania technologiczne i jak

\section{Introduction}

Ski jumping hills. Exceptional places. They are expensive structures, which are used by only a handful of users. However, this small number of competitors is usually observed by around a dozen thousand spectators. Up to the end of the twentieth century the dominant element in the construction of these structures was function. The turn of the century marked a shift in the design of ski jumping hills. Form, energy efficiency, environmentally friendly technological solutions and functional variety also started to matter. Numerous ski jumping hills no longer serve athletes and are converted into observation points. One can also eat a good meal at the top. One of the first examples of this new thinking is the Bergisel ski jumping hill in Innsbruck. As these structures were being adapted to changing safety and security requirements imposed by the FIS, as well as the increasing length of jumps, additional ski jumping hills were being remodelled. One of the most beautiful examples of ski jumping hills apart from Bergisel now include the Olympic ski jumping hill in Garmisch-Partenkirchen and Holmenkollenbakken in Oslo. In both cases the modernisations were selected on the basis of architectural competitions. Have ski jumping hills become safer to jumpers? How have technological solutions changed and how friendly to the environment are they? How 
bardzo są przyjazne środowisku? W jaki sposób wprowadzoniła się estetyka tych konstrukcji? Analizując trzy wymienione przykłady obiektów sportowych, autor poszukuje odpowiedzi na powyżej zadane pytania.

\section{Historia}

Pierwsze wzmianki o skokach z XI wieku pojawiają się w norweskich legendach'. W zapiskach z 1802 roku, kapitan holenderskiej marynarki Cornelius de Jong van Rodenburgh opisuje skoki żołnierzy norweskich z dachu szałasu². Pierwsze stałe skocznie powstały jednak dopiero w 1840 roku w miejscowości Telemark $w$ Norwegii a pierwszy rekord zanotowano w 1860 roku. 30,5 metra skoczył Sondre Nordheim. Jemu przypisuje się również rozwój skoków w tamtych czasach i doskonalenie techniki lotu. Pierwsze zawody odbyły się w Oslo w 1868 roku ale rekord Nordheima pobity został dopiero na w 1868 roku a rekod Nordheima pobity zostal dopiero na zawodach w Davos w 1902 roku $(40$ m.). W Stanach Zjednoczonych skoki stały się niezwykle popularne dzięki emigrantom z Norwegil. Na prerwsych igrzyskach olimpijskich w Chamonix nie zabrakło skoków narciarskich. Wygrali Norwegowie. W innych państwach ta dyscyplina zyskiwała popularność. Jeszcze z dziewiętnastego wieku pochodzi skocznia w Holmenkollen. W 1910 roku powstała pierwsza niewielka skocznia na Kalatówkach a w latach 1921-1930 funkcjonowała skocznia w dolinie Jaworzynki w Tatrach3. Niekorzystny dostęp, powstanie nowej skoczni w Zakopanem i częste kradzieże drewna z zeskoku przez górali przyczyniły się do rozebrania skoczni po 10 sezonach funkcjonowania4. W 1925 roku pojawiła się Wielka Krokiew. Niemcy i Czesi wybudowali swoje skocznie w Karkonoszach, Włosi w Cortinie d’Ampezzo a Szwajcarzy w St. Moritz.

II. 1 Konkurs skoków w 1916 roku, źródło: https://seerevelstoke.com/chris-rubens-on-the-history-of-ski-touring-in-revelstoke/, dostęp:

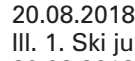

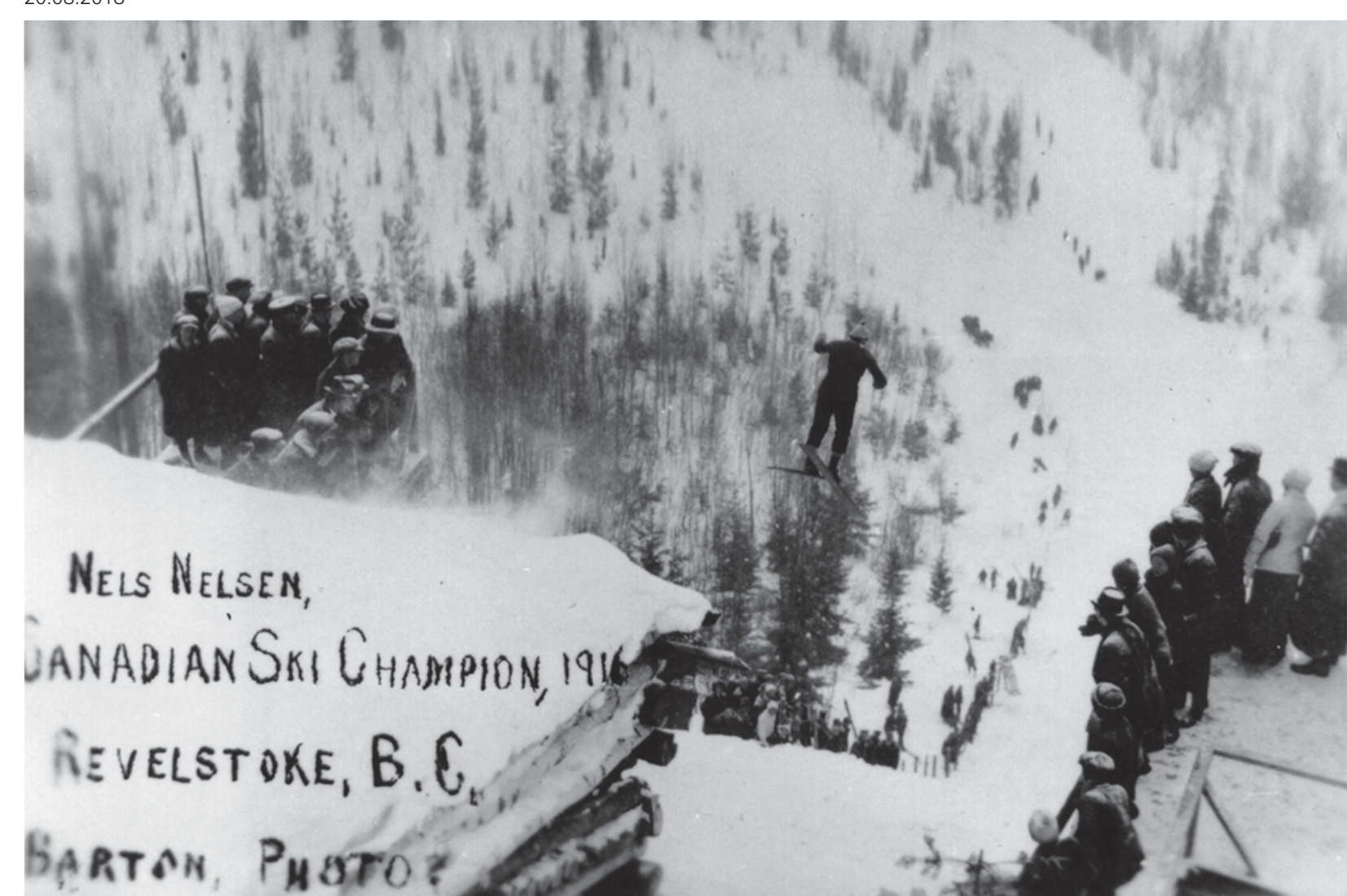

Popularność skoków odzwierciedlała budowa skoczni na calym świecie. W Polsce oprócz wczesniej wymienionych, od 1910 roku działa skocznia w Zniesieniu pod Lwowem zastapiona w 1935 roku nowoczesna w Brzuchowicach również pod Lwowem. Co ciekawe, skocznia w Zniesieniu była rozbierana na sezon letni. W 1922 roku powstała skocznia w Krynicy a w 1932 roku w Gdańsku Oliwie ${ }^{5}$. Wielkie reprezentacje skoków narciarskich trenowały i uczestniczyły w zawodach na dziesiatkach skoczni w Norwegii, Finlandii, Niemczech, Szwe cii, Austrii, Zauwaźć możn, że nawetw niekojarzonych z ta dy A Auplin Zaz nić pows w 1906 roku skecrie w Alyierze, która zymienic powsta w 1906 roku skeczie w Algierze, ko rastała ziczczona przed 10 wojn śchic

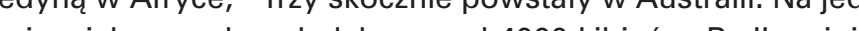

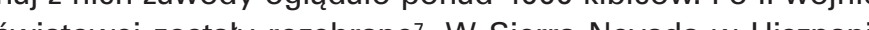

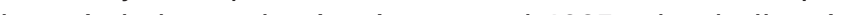
skocznia by a reguzoz bie uzwa od 1925 roku do Il wojny swiatowej. Nowozelandzka skocznia Mount Cook Aoraki powstała w 1931 roku. Ciekawym miejscem było Grytviken na wyspie Georgia Poludniowa (brytysskie terytorium zamorskie) na południowym Allantyku. Skocznia zostala wybudowan przez norweskich emigrantow przed II wojną swiatową ${ }^{9}$. Często w duzych miastach powstawaly tymczasowe skocznie narciarskie. Przodowały w tych realizacjach Stany Zjednoczone. Pierwszą skocznią wybudowaną na pojedyncze zawody była skocznia w Los Angeles na stadionie Hollywood Bowl w 1935 roku. W Chicago na stadionie pilkarskim Soldier Field odby się konkurs skoków w 1937 roku. 140 zawodników oglaadała 60 tysięczna publiczność. Zawody zorganizowano ponownie w 1954 roku $^{10}$. Konkurs na zbudowanej w Los Angeles w 1938 roku tymczasowej skoczni na stadionie Coliseum oglądało ok. 88 tysięcy widzów.

Po II wojnie światowej nastąpił zdecydowanie największy rozwój. W Polsce skocznie pojawiały sie $w$ wielu miastach nie tylko w górach. Skocznia w Warszawie na Mokotowie powstata w 1959 roku11, w Sopocie powstały kolejne ${ }^{12}$. Na świecie również pow tawaty skocznie w najóżniejszych ma świecie również nieco egzotycznych. W Australi powstaly dwien, w Chin h po W nie efekt

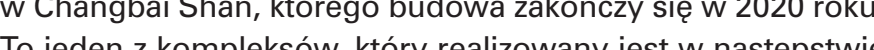
To jeden z kom lek o We Na Wegrzech powstalo 5 skoczni (jedna, przeznaczona dla mlodzieży wciazz dzlala). W Almaty w Kazachstanie powstały skocznie przebudowane w 2011 roku na Zimową Olimpiade Azjatycką. Obecnie odbywają się tu zawody najwyższej rangi w ramach Pucharu Swiata. W Hiszpanii powstało 8 skoczn dwie największe (Astun i La Molina) działały jeszcze w latach '90 XX wieku. Najstarsza z hiszpańskich skoczni została realizowana ze śniegu i z siana (Alto Campoo), najazd innej wykonano w niespotykanej technologii - w formie najazdu kamiennego (Nuria w Queralbs Caralps)'. W 1945 roku zrealizowano niewielką skocznię narciarską w San Carlos de Bariloche $w$ argentynskich Andach ${ }^{18}$. Skocznie powstały również w Lichtensteinie, Holandii, Wielkiej Brytanii, Nowej Zelandii. Popularnośc skoków mierzyć można było ilością organizowa- jumping. In Poland, apart from those mentioned previously, a ski jumping hill in Zniesienie near modern facility in Brzuchowice, also What is interesting, the ski jumping hill in Zniesienie was dismantled for the summer seasons. 1922 a ski jumping hill was built in Krynica, while national teams trained and participated in fitions hosted on tens of ski jumping hills in Norway, Finland, Germany, Sweden and Austria. even in obuntries that were not associated with this discipline. Here we can mention the facility in Algiers, built in 1906, which was destroyed prior only of its kind in Africa $a^{6}$. Three ski jumping hills were built in Australia. 4000 spectators could watch competitions held at one of them. After the Second World War they were dismantled'. The sti used from 1925 up to the Second World War The New Zealand ski jumping hill of Mount Cook Aoraki was built in 1931'. One interesting place was (a) jumping hill was built by Norwegian immigrant prior to the Second World War'. Temporary sk Jumping hills were often built in large cities. The the number of these projects. The first tek iums of hill built for a specific competition was the facility in Los Angeles, at the Hollywood Bowl stadium, 1935. In Chicago, a ski jumping competition was
held in 1937 at the Soldier Field football stadium. 140 competitors were watched by 60 thousand spectators. The competition was once again organised in $1954^{10}$. The competition held at the temporary ski jumping hill built in Los Angeles at th88 thousand spectators.

The period after the Second World War saw the greatest development in this field. In Poland ski cluding those outside of mountainous areas. The ski jumping hill in Warsaw's Mokotów was built
in 195911, with additional ones being built in Soin $1959^{11}$, with additional ones being built in So-
pot $^{12}$. Ski jumping hills were also built in all sorts of places round the world, sometimes even quite exotic ones. Two have been built in Australia $a^{13}$
in China- 5 , and all are operational to this day ${ }^{14}$, The modern Wangtien complex of ski jumping its completion being slated for 2020. It is one of the complexes that are being built as a result of Five ski jumping hills werere orilt in $\mathrm{H}$ a in 2006 of them, meant for juniors, is still open $)^{16}$. In Al-
of maty, Kazakhstan, ski jumping hills were built and later remodelled in 2011 on the occasion of the Aslan Winter Olympics. They currently host top ski jumping hills were built in Spain, and the two largest ones (Astún and La Molina) were operating as late as the 1990's. The oldest of the Span(Alto Campoo), while the in-run of another one was built using unique technology -in the form of a stone in-run (Nuria in Queralbs Caralps) ${ }^{11}$. In 1945 a small ski jumping hill was built in Sa Such facilities were also built in Lichtenstein, the Netherlands, Great Britain and New Zealand. The popularity of ski jumping could be measured by
the number of competitions, as well as of the 


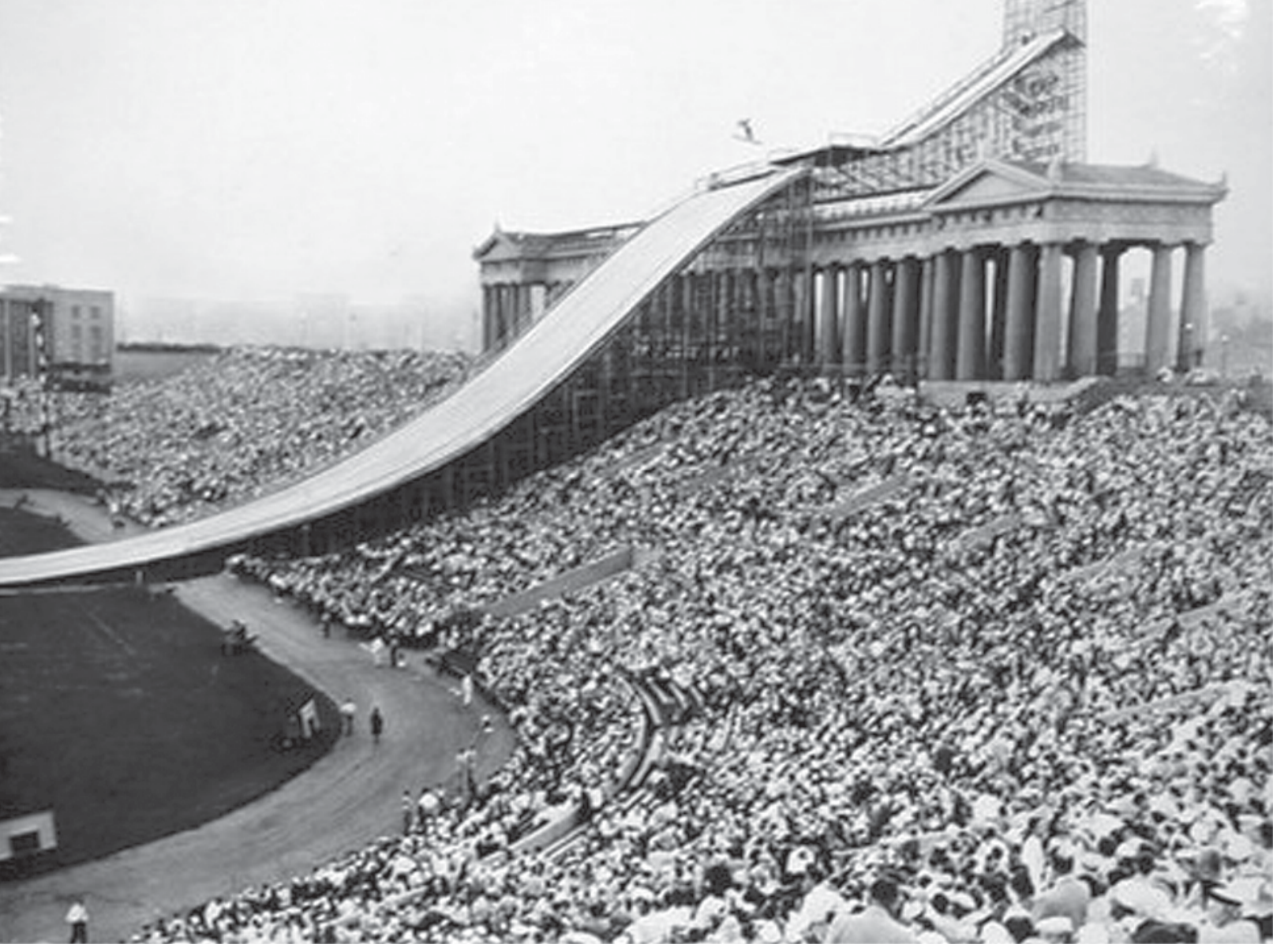

II. 2 Konkurs skoków w Chicago na stadionie Soldier Field w 1954 roku, źród

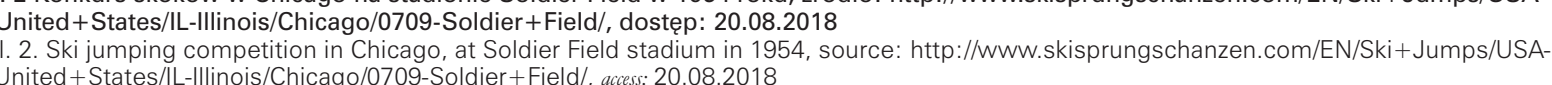

nych zawodów i zgromadzonych kibiców. Podobnie jak przed II wojną światową w Stanach Zjednoczonych, w Wielkiej Brytanii również realizowano skocznie tymczasowe. Jedną z nich była skocznia na stadionie Wembley $w$ Londynie, gdzie tysiące kibiców oglądało bardzo mocno obsadzone zawody w 1961 roku19. Niedościgniony konkurs odbył sie wcześniej w Hamptead 25 marca 1950 roku na tymczasomej skoczni, który

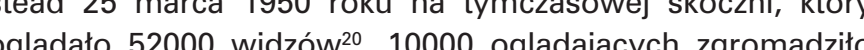

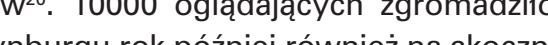
sę na zawodach w Edynburgu rok poźniej rowniez na skoczni

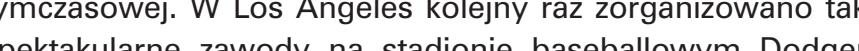

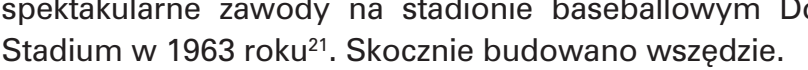
Jednak w latach '70 i '80 poprzedniego wieku skocznie podJedien w i upadaly. Brakow '70 i '80 poprza nich utrymanie. Zainteresowanie widzow mo lo wiania tej dyscypliny. Jedną z najbardziej spektakularnych skoczni wciąz istniejących lecz niszczejących jest skocznia Copper Peak w Stanach Zjednoczonych w Ironwood. Pięknie położona, jest najmniejszą ze skoczni mamucich. Powstała w 1969 roku dziśs stoi zaniedbana. Jednak powstają plany powrotu obiektu do dawnej świetności. Generalnie w Stanach zjednoczonych powstato ponad 120 skoczni. Obecnie użytkowanych jest kilka. Te zbudowane na Igrzyska Olimpijskie, zbudowane na początku wieku również stoją nieczynne. Większość istniejących budowli została w pierwszej dekadzie XXI wieku rozebrana. Koszty użytkowania, brak zainteresowanych, niszczejąca infrastruktura są głównymi przyczynam spectators who watched them. Similarly as before the Second World War in the United States, temporary ski jumping hills were built in Great Britain. Stadium in London, where thousands of spectators watched the competition of 1961, featuring all-sta

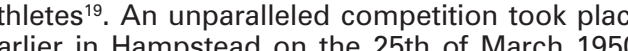
so on a temporary ski jumping hill, watched by 52000 spectators $^{20}$. An audience of 10000 people litho gathered at he temporary ski jumping hill in nce again organised in Los Angeles at Dodger Stadium, a baseball venue, in $1963^{21}$. Ski jumping Sils were being built practically everywhere.
. foll of ski jumping hills. There were now the downhem operational. The audience's interest faded there were often no people interested in practicing tectering ski jumping hills is Coper Peak onwood, United States. Beautifully located, it is he smallest of ski flying hills (sometimes referred to as "mammoth" jumping hills). Built in 1969, to bring the structure back to its former glory. In general, over 120 ski jumping hills have been built in he United States. Only a few are currently in use. of existing buildings was dismantled in the first decade of the twenty-first century. Maintenance costs, lack of interest and decaying infrastructure are the cilities. Due to the cost of building a ski jumping hil year later. Such a the competition held ther

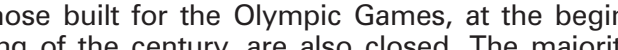
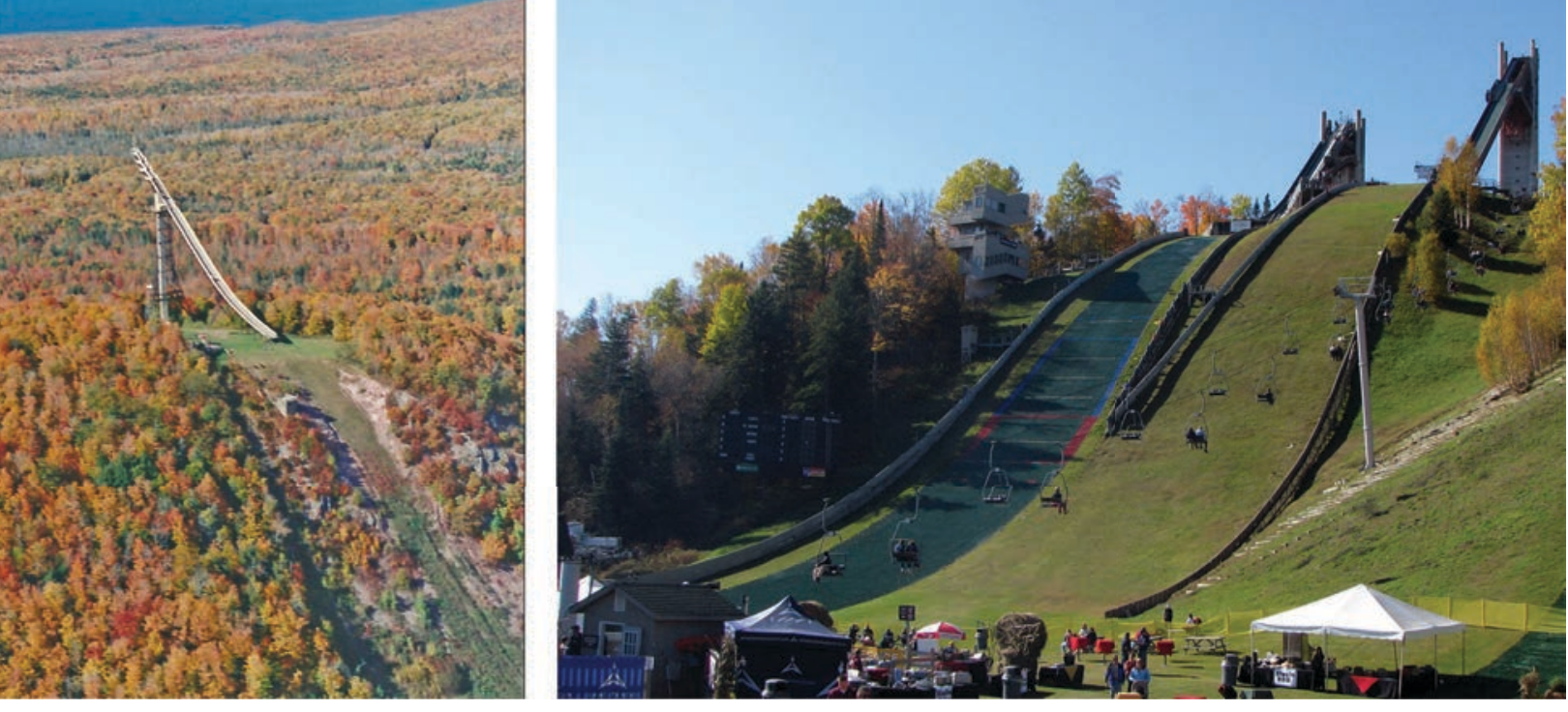

II. 3 Nieuizttkowana skocznia Copper Peak w Ironwood is skocznie olimpijskie w Lake Placid., źródto: www.northernlightslodging.net//single dostep: 20.08 .2018
III. 3. The shut down Copper Hill ski jumping hill in Ironwood, as well as the ski jumping hills in Lake Placid., source: www.northernlightslodging net/single-post/2018/01/177/Red-Bull-Event-coming-to-Copper-Peak-May-12-2018 and https://en.wikipedia.org//wiki/Lake_Placid_Olympic_Ski_Jumping_Complex, acess: 20.08.2018

demontażu obiektów. Ze względu na fakt, iż koszt realizacil skoczni dla niewielkiej ilości zawodników brak widzów, ciągle (2) (głównie dotyczące bezpieczenstwa skaczących zawodników) kluby narciarskie i właściciele skoczni nie są w stanie podołac utrzymaniu swoich obiektów.

Skoki się zmieniają, jedynie pełne dostosowanie do wymogow FIS sprawic może, ze na tych skoczniach organizowane będą międzynarodowe zawody narciarskie. Organizacja zawodów najwyzszej rangi oznacza dopływ pieniędzy z reklam sprzedaży transmisji telewizyjnych i sprzedaży biletów. Obecnie jest kilka miejsc na świecie, które gromadza mnóstwo widzów. Planica, Zakopane, skocznie Turnieju 4 Skoczni, Holmenkollen - to tu gromadzą się kibice. Często na pozostałyc skoczniach podczas pucharu świata gromadzi sie kilkuset kibiców, gtównie turystów, którzy po jeździe na nartach ida pokibicować zad miejskie zrezygnowały z utrzymywania skoczni olimpijskiej (Olimpiada Zimowa w Turynie), gdyż we Włoszech obecnie nie ma osiagających spektakularne wynik zawodników, kibiców brakuje, nie ma środków na utrzymanie skoczni. W najbliższych latach rozbieg, wyciag narciarsk i wieża sedziowska zostaną zdemontowane, natomiast zeskok ma zostać wykorzystany na inne cele.

3. Nowa funkcjonalność

Jakie muszą być nowoczesne skocznie, by mogły być wykorzystywane przez cały rok poza dwudniowym wydarzeniem Pucharu Świata i by właściciele byli w stanie utrzymać obiek i co jakiś czas modernizować go dostosowując do nowych wymogów FIS?

Pierwszym, elementem jest architektura skoczni. Najczęściej najnowsze realizacje powstaja w następstwie konkursów architektonicznych. Modernizowana skocznia musi by architektonicznie piękna ${ }^{22}$. Większośc spełnia ten warunek. Skocznie znajdują się w niewielkich miejscowościach i sa one dla włodarzy tychże miast wizytówkami, ikonami. Wisła for a small amount of athletes, with there being no in the shape of the in-run and jump sections, as we as infrastructure (primarily concerning the safety of jumping competitors), skiling clubs and ski jumping Ski jumping is changing, with only full compliance whe cilities. The organisation of top-level competitions means an inflow of money from advertising, the sale currently is only a small number of places that attract large crowds of spectators. Planica, Zakopane, the menkollen -it is here that ski jumping fans gatheThe remaining ski jumping hills often only see several hundred spectators during the world cup, most of them being tourists, who, during a break in skiing One example of this is Predazzo. The municipal authorities abandoned the maintenance of the Olympic ski jumping hill (the Turin Winter Olympics), as results in Italy there is a lack of fans and spectacula maintain the hills. In the coming years the in-run, ski lift and jury tower will be dismanntled, while the jump
section is to be used for other purposes.

3. New functionality

How should modern ski jumping hills look like in order to provide services throughout the entire Cup and for their owners to be able to maintain the acilities and modernise them from time to time in order to adapt them to new FIS requirements? ing hill. Most often, the latest built projects are erected as a result of architectural competitions. A ski jumping hill that is being modernised must be architecturally beautiful22. Most facilities meet his condition. Ski jumping hills are located in sma icons by their respective local authorities. Wisła is primarily associated with the Adam Małysz ski Jumping hill, while Zakopane, apart from Giewont ated with Wielka Krokiew. Garmisch-Partenkirchen, in turn, has the Olympic Ski Jumping Hill and 


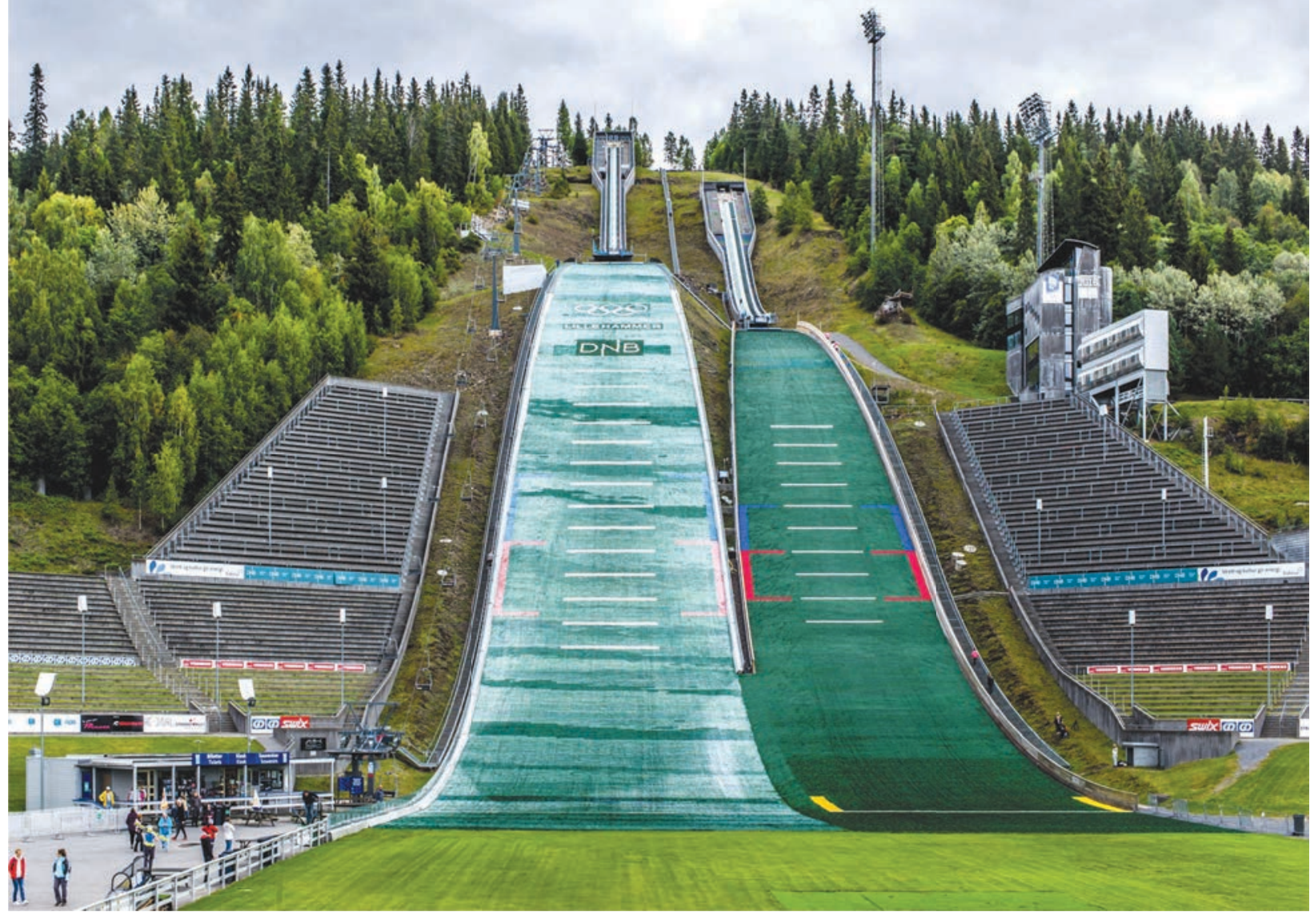

II. 4 Skocznie olimpijskie w Lillehammer w Norwegii., fot. Mariusz Twardowski
III. 4. Olympic ski jumping hills in Lillehammer, phot. by Mariusz Twardowski

jednoznacznie kojarzona jest ze skocznią im. Adama Małysza Zakopane poza Giewontem, Kasprowym I Morskim Okiem kojarzone jest z Wielką Krokwią. Garmisch-Partenkirchen ze Skocznią Olimpijską i zawodami odbywającymi się w Nowy Rok, Oslo to Holmenkollen i nowa opera, Kranjska Gora to Planica i najwyższy w Alpach Julijskich szczyt Triglav, itd.

Kolejnym elementem są funkcje pozasportowe, które sprawia, że skocznia będzie odwiedzana poza zawodami Pucharu Świata. Restauracje, platformy widokowe, przestrzenie publiczne, które wykorzystywane sa na wydarzenia niezwizzane (a) ze skokami, wy galerie przyciągąa zwiedzających

Inwestycje w rozwiązania chroniące bezpieczeństwo zawodników jak siatki, osłony, rozwiązania smart wspomagające funkcjonowanie skoczni, windy i wyciągi również są istotne we wszystkich aspektach funkcjonowania skoczni od bezpie-

4. Najlepsze przykłady: Bergisel w Innsbrucku, Skocznia Olimpijska w Garmisch-Partenkirchen, Holmenkollenbakken w Oslo

Pierwszą z opisywanych skoczni jest Bergisel w Innsbrucku. Została zrealizowana w 2001 roku. Została zaprojektowan przez Zahę Hadid $^{23}$. Została skonstruowana w 1927 roku. Pierwszy rekord to $47.5 \mathrm{~m}$. Po roku funkcjonowania dobudowano wieżę startową a rekord skoku poprawiono do $63 \mathrm{~m}$. W 1941 roku runęła wieża startowa zabijając 4 osoby. Po II wojnie światowej obiekt gruntownie przebudowano. Od 1953 roku obiekt gości zawodników w ramach najsłynniejszych za- the competitions that are held on New Year's Day, the Julian Alps. Triglav, and so on and so on. Another element are functions not associated with sports, which cause the ski jumping hill to be visited during the time when the World Cup events platforms, public spaces that are used for events that are not associated with ski jumping, public functions like museums or galleries that attrac visitors.

Investment in solutions that ensure the safety of competitors, such as nets, protective guards, or jumping hill, elevators and ski lifts are also essential in all aspects of a ski jumping hill's operation ranging from safeguarding
of judges and spectators.

4. The best examples: Bergisel in Inssbruck, the Olympic Ski Jumping Hils in Gamisch-Part The first of the ski jumping hills to

we is Bergisel, in Innsbruck. Its current versio was built in 2001 and designed by Zaha Hadid ${ }^{23}$. It up to $63 \mathrm{~m}$. In 1941 the tower collapsed, killing came a host facility for the most famous skijumpecompetition-The Four Hills Tournament ${ }^{2}$. Bergise hosted ski jumping competitions as a part of WinOlympic Games, and the second time in 1976 , as Kranisa

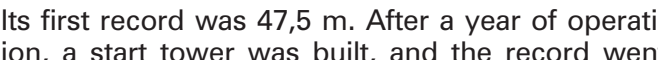
people. After the Second World War the facility was ter Olympic Games two times. Bergisel first hosted

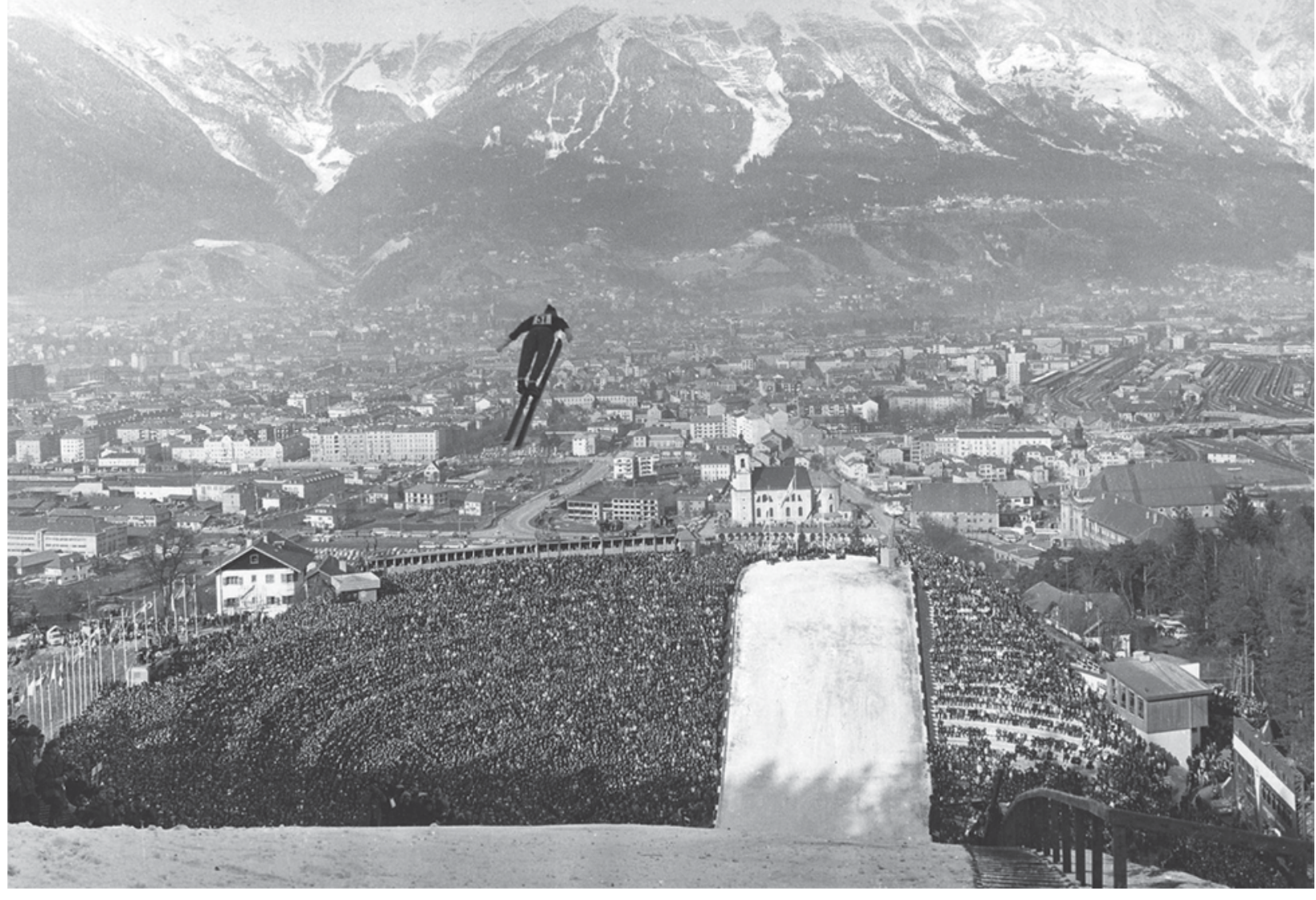

II. 5 Skocznia Bergisel w Innsbrucku, konkurs skoków podczas IX Zimowych Igrzysk Olimpijskich w 1964 r., źródto: www.lindro.it/olimpiadi-

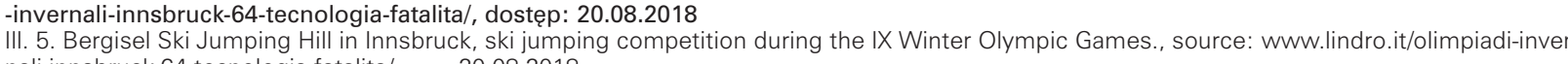

wodów narciarskich - Turnieju Czterech Skoczni²4. Na Bergisel dwakrotnie odbyly sie konkursy skokow w ramach zimowych olimpiad. Pierwszy raz Innsbruck goscił olimpijczyków w 1964 roku w ramach IX Zimowych Igrzysk Olimpijskich a drugi raz w 1976 roku w ramach XII Zimowych Igrzysk Olimpijskich. Ten drugi raz był niejako przypadkowy, ponieważ 4 lata przed olimpiada, z organizacji wycofało sie amerykańskie Denver a jedynie Innsbruck po niewielkiej modernizacji posiadał pełną infrastrukture by udźwignaćc cięzar olimpiady. To wtedy powstała żelbetowa wieża startowa. Od tamtej pory w zasadzie ws zroje ko zadzie w Za roz oraz powiek wie lądują poniżej poziomu ter przeciwstoku. $Z$ braku miejsca, trybuny zaprojektowane są n zucie w formie okręów. Mleszczą one 22500 widzów. Górn rzędy obrócone są w stronę dołu skoczni. Na górny poziom wzgórza, mijając wieżę sędziowską, wyjeżdża się windą jadącą po skosie (pojazdy techniczne mają wytyczoną asfaltowa drogę). Na tym poziomie znajduje się miasteczko skoczków budowane na czas zawodów. Tu rozpoczyna się ascetyczn wieża startowa. Zaha Hadid narysowała wieżę jedną linią. Forma żelbetowa biegnie w górę by na szczycie wieży zawinąc kzztalt, plynnie zmienic się w zeskok i zakończyć się na progu. To studium formalnej ekspresji. Zgrabne linie i minimalistyczna estetyka tworzą zmysłowy, szybki ruch, odzwierciedlający dynamiczną formę skoczni, jej monumentalną konstrukcję a part of the XII Winter Olympic Games. The second time was sott of accidental, because the American competition 4 years prior and on organising th the necessary infrastructure to bear the weight of the games, albeit requiring a slight modernisation. was then that the concrete starting tower was cally not modernised at all. It was the competition design by Zaha Hadid that changed the shape and character of the ski jump-

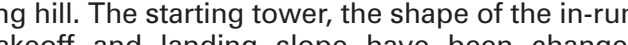
takeoff and landing slope have been changed
completely, while spectator stands were expanded. The shape of the stands is extraordinary, as the landing slope was made deeper with each moda recess and come to a halt on a gackslope. Due to a lack of space, the spectator stands were designed with a circular floor plan. They have a capacity of 22500 people. The upper rows are turned upper part of the hill, passing the jury tower. is accessed by an elevator that travels diagonally (technical vehicles travel using an asphalt road). This level features facilities for jumpers, which are built
for specific competitions. This is also where the ascetic starting tower starts. Zaha Hadid drew the tower with a single line. The concrete form runs upwards and twists itself at the top of the tower, fluidly transforming into the in-run and ends at the takeoff point. It is a study in formal expression,
The elegant lines and minimalist aesthetic create a quick sensual motion, reflecting the dynamic form of the ski jumping hill and its monumental structure, which stands above the historical city centre of Innsbruck
slopes around it $\mathrm{t}^{25}$. 


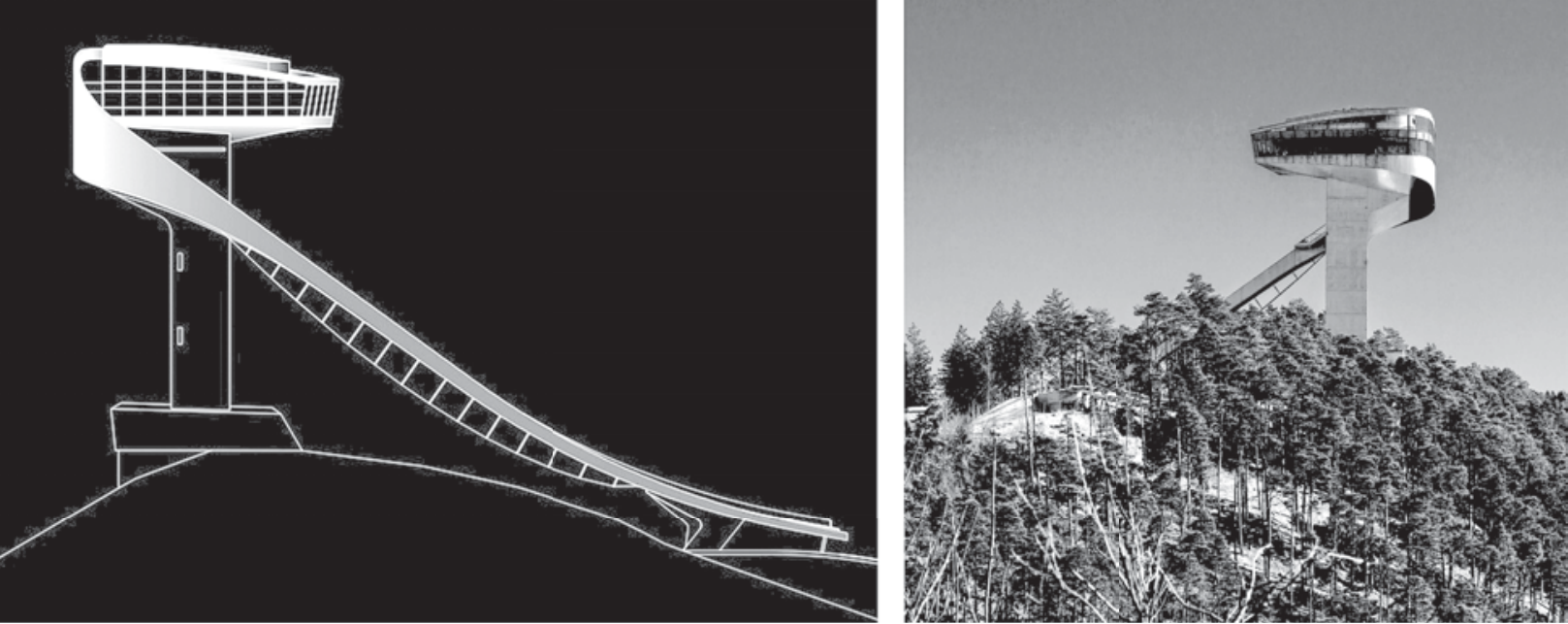

II. 6. Skocznia Bergisel w Innsbrucku, elewacje, rys: Żródto: www.zaha-hadid.com/architecture/bergisel-ski-jump/, fot. Mariusz Twardowski
III. . . Bergisel ski jumpinh hill, Innsbruck, drawing: source: Wwww.zaha-hadid.com/architecture/bergisel-ski-jump/, phot. by Mariusz Twardowski

która stoi powyżej historycznego centrum Innsbrucka i naprzeciw górskich stoków wokół ${ }^{25}$.

Jednym z obowiązkowych punktów konkursowych było wymaganie Austriackiej Federacji Narciarskiej, że skocznia ma stać się pomnikiem i ikoną sportów klasycznych w Innsbrucku. Wieża skoczni projektu Zahy Hadid wysoka na $50 \mathrm{~m}$. ponad szczyt góry Bergisel, z rozbiegiem długim na $90 \mathrm{~m}$. stała się takim wielkim pomnikiem, który wystaje ponad czubki otaczających drzew. Jednak ksztatt, linia rozbiegu kontynuująca linię zbocza góry, w pewien sposób stara się nie przytloczyć góry. Projektantka opisała swój projekt jako „organiczną hybrydę" - coś pomiędzy wieżą a mostem. Wieża to szyb o rzucie kwadratu dł. boków $7 \mathrm{~m}$. a most to jakby wiszący pomiędzy progiem a belką startową rozbieg ${ }^{26}$. Nie chodziło o wybudowanie żelbetowej wieży $i$ wiszącego rozbiegu by spełnić program funkcjonalny ani też nie chodziło jedynie o wizualny charakter zaprojektowanych form. Ta organiczna hybrydowość odnosi

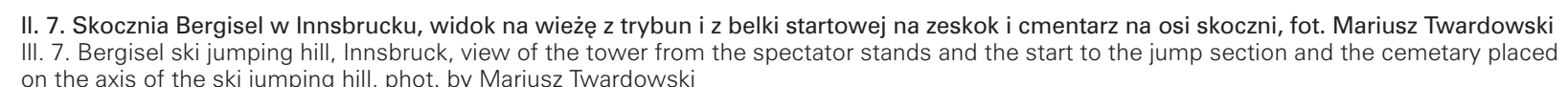
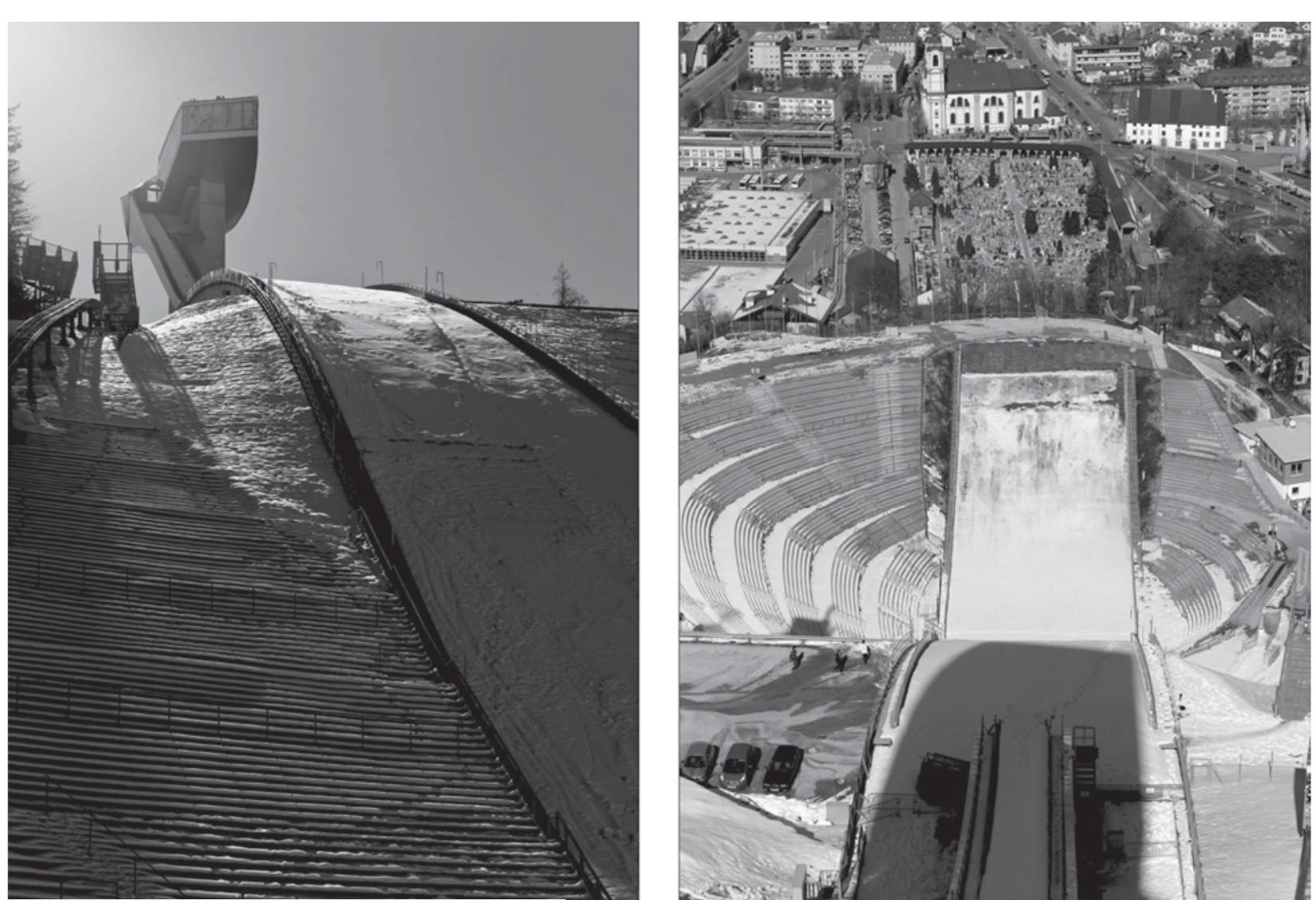

One of the mandatory competition guidelines was
the requirement formulated by the Austrian Skiing Federation to have the ski jumping hill become a monument and icon of classic sports in Innsbruck. The ski jumping hill tower designed by Zaha
Hadid, which rises $50 \mathrm{~m}$ above the peak of Bergise surrounding trees. However, the shape, the line of the in-run that continues the line of the mountai shadow the mountain itself.

The designer described her design as an "organic hybrid"-something between a tower and a bridge. The tower is a shatt with a square floor plan, with that looks as if it has been suspended between the concrete tower and a suspended in-run in order meet the criteria of the functional programme this organic hybrid starts and the takeoff 26 . This was not about building

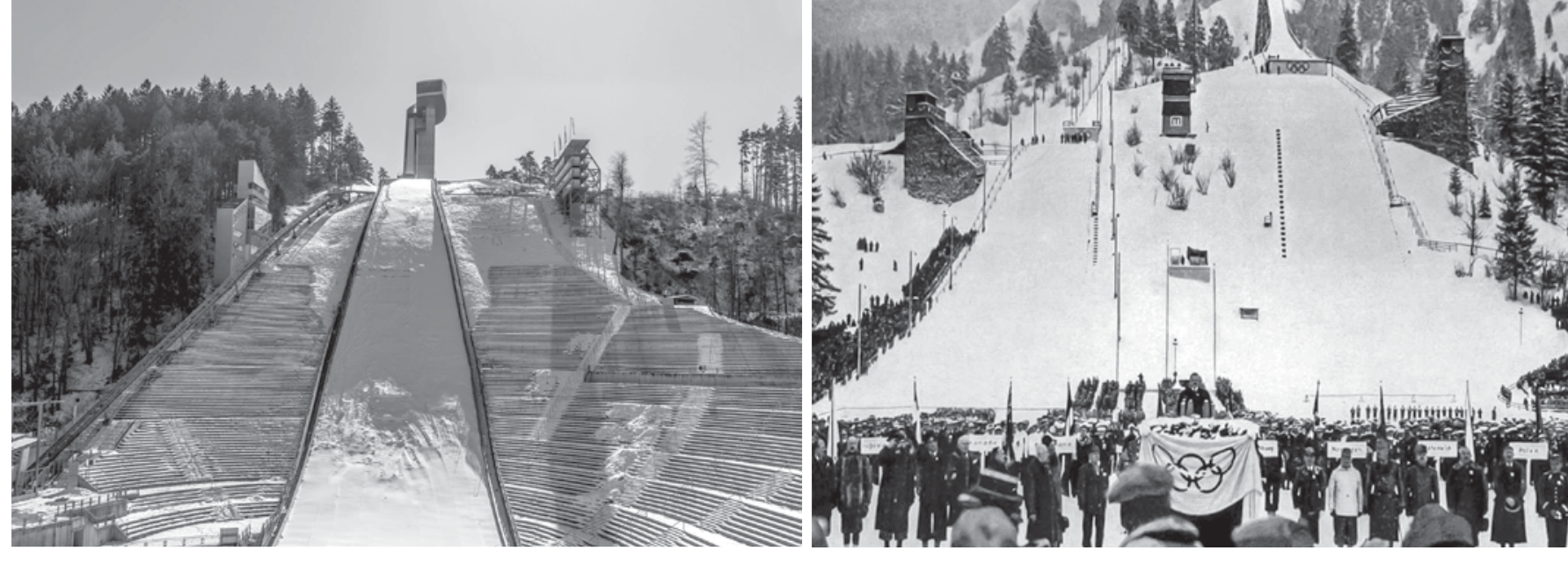

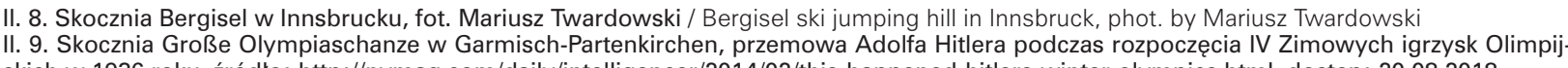

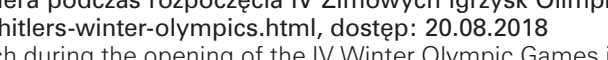

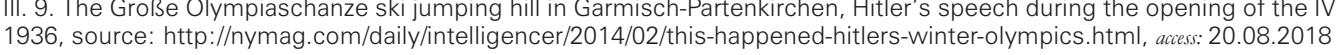

się tu również do prędkości, ruchu i lotu skoczków, które razem zdefiniowały tak dynamiczny kształt bryły.

Na górne poziomy wieży prowadza dwie windy i klatka schodowa wewnatrz żelbetowej konstrukcji. Już z górnych trybun rozpościera sie wspaniały widok na Innsbruck. Jednak

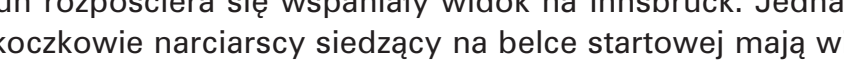
dok na otaczające góry, lotnisko, miasto $i . .$. cmentarz. Skoczkowie z uśmiechem mawiaja, że: „Kiedy jest się w bardzo wysokiej formie, možna odniesć wrazenie, ze przeskoczy sie skocznię i wyląduje się na głównej alejce tego cmentarza" 22 . Zaha Hadid na szczycie zaprojektowała również teras widokowy, z którego roztacza się $360^{\circ}$ widok na Innsbruck, Alpy austriackie i włoskie Dolomity na południe. Zaprojektowała również niewielką restaurację otwartą dla zwiedzających skocznię poza okresem konkursów. W czasie zawodów odpoczywaja tam zawodnicy przed swoimi skokami. Restauracja zamieniana jest w pokój, w którym zawodnicy moga sie odprężyć, skupić oraz posilićć. Na najniższej kondygnaci wieży znajduja sie toalety, magazyny i pomieszczenia tech-

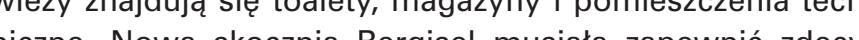
niczy. Dlatego oprócz funkcii spotowej powstato tak dużo fuzka. towarzyszacych. owarzyszących.

Niestety, już podczas budowy skoczni wielu mieszkańców protestowało przed realizacja tak nowoczesnej bryły widniejącej nad ich miastem. Próbowano wskazywać, na historyczná zabudowę Innsbrucka, na budowle sięgające czasow sredniowiecza. Pomimo sprzeciwów, nowa skocznia narciarska została zrealizowana zgodnie z projektem Zahy Hadid i obecnie jest jedną z najpopularniejszych skoczn Turnieju Czterech Skoczni i lubianym obiektem odwiedzanym przez turystów przybywających do Insbrucka z całego swiata. Skocznia Bergisel stała się punktem zwrotnym również z innego powodu. Była pierwszym, tak nowoczesnym obiektem w tkance miejskiej Innsbrucka. Otwarła szanse na realizacje innych, nowatorskich budowli w tym mieście. Innsbruck w XXI wieku stał się poza Wiedniem największym ośrodkiem w którym stara i nowa architektura umiejętnie współgra ze sobą. quality refers to the speed, motion and flight of the
jumpers as well, which have defined this dynamic One can get to the upper levels of the tower using two elevators and a stairwell inside the constrete structure. A wonderful view of Innsbruck tretches out already from the upper specta-
tor stands. However, ski jumpers who sit on the starter have a view of the surrounding mountains, the airport, the city and... a cemetery. The jumpyou can get the impression that you ared shape jump out of the ski jumping hill and land on the main path of that cemetery" ${ }^{27}$. Zaha Hadid also designed an observation terrace at the top, from the Austrian Alps and the Italian Dolomites to the south. She also designed a small restauran open to visitors of the ski jumping hill outside of competition season. During the competition it is converted into a room in which they can relax focus and regain their strength ${ }^{28}$. At the lowest level of the tower there are toilets, storage spaces and technical facilities. The new ski jumping hill in Bergisel had to provide a much greater variety of
functions than its predecessor. This is why, apart from sports-related functions, it features so many

accompanying ones.
Unfortunately, many residents protested against
building such a modern massing above their city building such a modern massing above their city
already during its construction. They pointed to the historical buildings of Innsbruck, buildings whose history had been dated to the Middle Ages. Despite he protests, the new ski jumping hill was built in
accordance with Zaha Hadid's design and is now one of the most popular facilities of the Four Hills Tournament, well-liked and often visited by tourists coming to Innsbruck from all over the world ing point for a different reason. It was the first such modern structure within Innsbruck's urban tissue. It paved the way for the construction of other innovacive structures in the city. In the twenty first century centre in which both old and new architecture skit fully blended in with one another.

Another extraordinary ski jumping hill is the Große 2008 in accordance with a design by Terrain: Loenhart \& Mayr. 
Inną niezwykłą skocznią jest Große Olympiaschanze w Garmisch-Partenkirchen zrealizowany w 2008 roku projektu zespołu Terrain: Loenhart\&Mayr.

Skocznia stanowi część kompleksu kilku skoczni (z normalna oraz skoczniami dla młodzieży) które posiadaja wspólny zeskok otoczony trybunami dla 35 tysięcy widzów powstałymi na IV Zimowe Igrzyska Olimpiijkie w 1936 roku. Oprócz konkursu skoków (ogląanego przez 130 tysieccy widzów) odbyła miec Adolfa Hitlera. Każdego roku 1 stycznia odbywa się tu konkurs z cyklu Turnieju Czterech Skoczni.

Konkurs architektoniczny, w którym brały udział między innymi Zaha Hadid i Benisch Architekten wygrało biuro projektowe terrain:loenhart\&mayr profesora Klausa Loenharta i Christopha Mayra. W kwietniu 2007 roku, za pomocą tadunków wybuchowych wysadzono stara skocznie. Rozpoczeła sie budowa nowej. Ciekawym rozwiazzaniem była realizacja wieży „na leżąco". Kiedy cała konstrukcja wraz z płytami elewacyjnymi została zamontowana, na zamontowanych przegubach podniesiono skocznię i zamontowano kolejne elementy skoczni. Ceremonia otwarcia odbyła się w Nowy Rok 2008 r. Jednak nie wszystko przebiegło jak należy. Jak wspomina Dawid Kubacki, „pod wiezę skoczkow dowoziła nowa kolejka (kapsuła jadąca po szynach), jednak windy w wieży nie zdążono zamontowac i skoczkowie mieli niezłą rozgrzewkę wychodząc po 332 stopniach $w$ butach narciarskich $\mathrm{z}$ nartami na barkach"

Podobnie jak w Innsbrucku, skocznia stała się punktem orientacyjnym i ikoną sportów zimowych w Garmisch-Partenkirchen. Inspiracją kształtu skoczni dla projektantów była topografia góry Gudiberg, na której zboczu usytuowany jest cały kompleks. Łagodne krzywe zeskoku i wieży są reminiscencją form otaczających łańcuchów górskich ${ }^{30}$. Dynamiczna a zarazem rzeźbiarska forma skoczni kształtuje krajobraz oraz zwieksza wrażenie ryzyka jakie podejmuja skoczkowie lecac nad zeskokiem. Dażenie do przezwycièzenia grawitacii podkreślone jest delikatną kreską zeskoku oderwanego od podłoża.

Skoczi nazy zesko przez zawodników podioża. nikiem" prezentuje sie bardzo elegancko na tle zim wsporGudiberg. Cała konstrukcja wieży zostata pokryta pótpory zroczystymi elementami z poliwęglanu, której wygląd zmie-
The ski jumping hill constitutes a part of a complex juniors) which shith a standard facility and one for Apart from a ski jumping competition (watched by 130 thousand spers of the Four Hills Tournament

The architectural competition, in which, among ten had also participated in, was won by the terrain:Ioenhartgmayr design office, headed by professor Klaus Loenhart and Christoph Mayr.
April 2007, with the help of demolition charges, the old ski jumping hill was demolished. The construction of a new one began immediately. Solving the tower is if it were "prone" is an interesting opening ceremony took place on New Year's Day plan. Dawid Kubacki: "the jumpers were carried by a new carriage (a capsule that moved on rails), however, the elevators inside the tower had no a warm-up, going up 332 steps in skiing boots with skis on their shoulders" came an orientation point and an icon of winte for the shape of the hill was the topography of is situated. The gentle curves of the jumping secof the surrounding mountain chain ${ }^{30}$. The tormushapes the landscape and increases the impression of the risk taken by the jumpers when flying above highlighted by the delicate line of the jump section that is separated from the ground.
The ski jumping hill, called the "Olympian cantilever" by competitors, presents itself in a very ele-
gant manner against the background of the greenery of Gudiberg Mountain. The entire structure of the tower has been covered by semi-translucen elements from polycarbonate, whose appearance
changes depending on daylight and artificial rounded by spectator stands for 35 thousand suple built for the IV Winter Olympic Games in 1936. German chancellor Adolf Hitler. A competition is held here on the first of January each year as a part ing hill was raised up on special joints, with additional elements being assembled afterwards. The

Similarly as in Innsbruck, the ski jumping hill be Gudiberg Mountain, on whose slope the complex taneously dynamic and sculptural form of the hill

II. 10. Wieża skoczni Große Olympiaschanze w Garmisch-Partenkirchen, fot. Mariusz Twardowski
III. 10. The tower of the Große Olympiaschanze ski jumping hill in Garmisch-Partenkirchen, phot. by Mariusz Twardowski
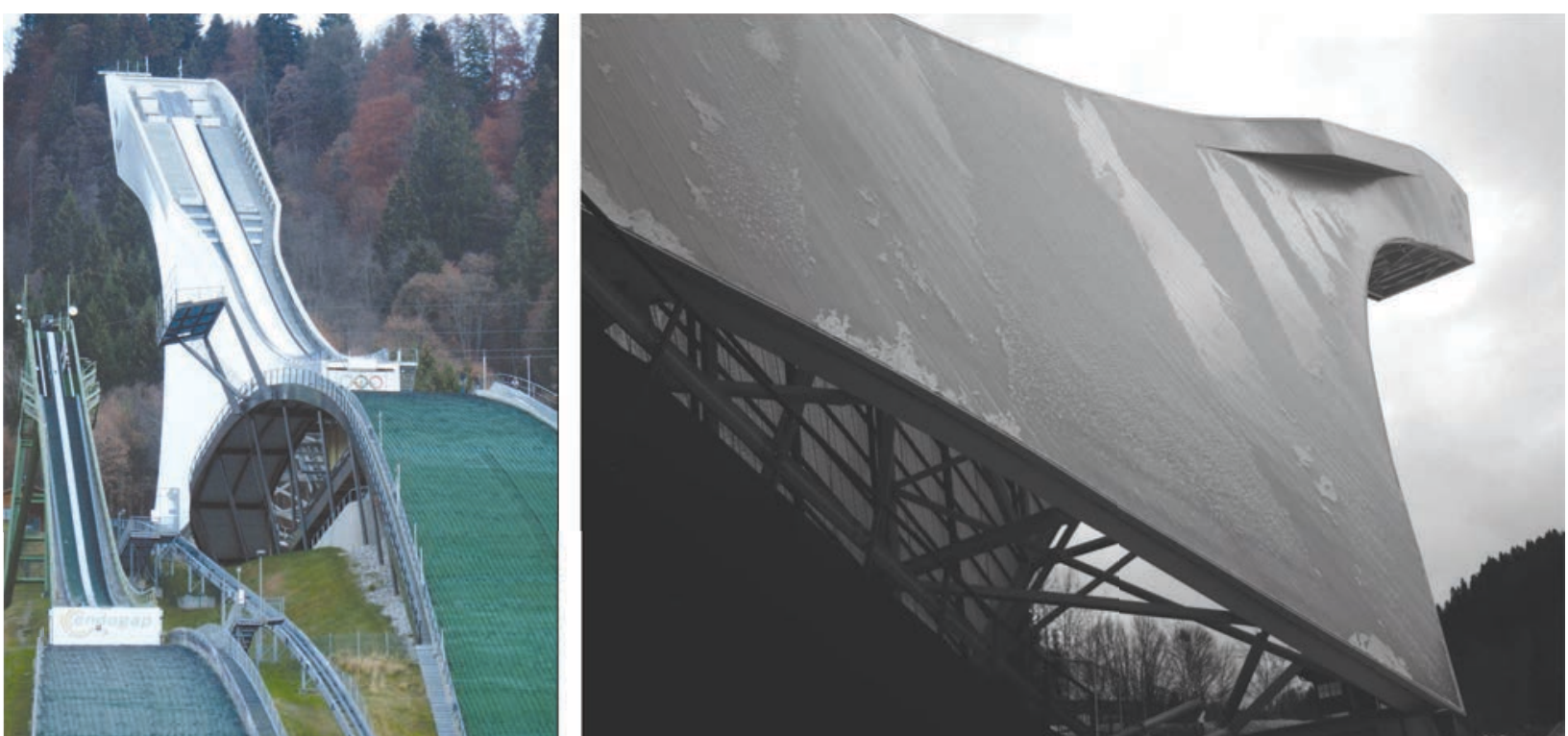

II. 11. Skocznia Große Olympiaschanze w Garmisch-Partenkirchen, fot. Mariusz Twardowski

11. 12. Sko Großse Olympiaschanze ski jumping hill in Garmisch-Partenkirchen, phot. by Mariusz Twardowsk

can.com/featured/oslos-2022-olympic-winter-games-and-delusions-of-grandeurl, dostęp: 20.08.2018 1952 roku, źródto: wWw.norwegianameri-

III. 12. The Holmenkollen ski jumping hill in Oslo, ski jumping competition held during the VI Winter Olympic Games in 1952, source: wuw.norwe

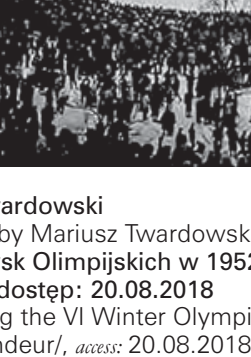

nia się przy świetle dziennym i sztucznym oświetleniu. Biała, półprzeźroczysta budowla rysuje swoje pofalowane kształty na tle śniegu i nieba. Pojawiajace sie światto słoneczne na biatych panelach i miejsca zacienione tworzą harmonijną całość z krajobrazem. Po zachodzie słońca, sztuczne światto oświetlające bryłę od środka zamienia tenże "wspornik” w rzeźbe widoczna z całego miasta ${ }^{3}$

$\mathrm{Na}$ trzy poziomy wieży prowadzi winda i 332 wspomniane wczesniej stopnie. Kiedy na skoczni nie odbywają się zawody lub treningi, turyści mogą wspiąc się na czubek wiezy i zachwycac się doliną Garmisch-Partenkirchen. Na görze nie ma jednak restauracji jak w Innsbrucku. Ta znajduje sie $n$ trybunach. Jest większa i służy czasem jako centrum konferencyjne. Przedwojenne trybuny sa obecnie remontowane. Instaluje się nowoczesne krzesełka. Pod trybunami znajduja się różne pomieszczenia służące turystom (sklepik, muzeum) oraz klubowi narciarskiemu w Garmisch-Partenkirchen.

Ciekawym rozwiązaniem jest takie uksztaltowanie zeskoku i rozbiegu, że do schłodzenia torów i utrzymania śniegu ieskoku potrzebna jest minimalna ilość energii. Igielit pozwala na użytkowanie skoczni w lecie.

Ostatnim opisywanym przykładem jest skocznia HolmenkolO22 w Oslo zrealizow pra w 2010 roku wedlug projeknko- $/$ Julien De Smedt Architects.

Pierwsza skocznia Husebybakken powstała tu w 1879 roku Pierwsza skocznia Husebybakken powstała tu w 1879 rok zastapiona zostala przez Holmenkollbakken w 1892 roku. W lgrzysk Olmpijskich. Whedy zbudowano tu state trybuny a konkursowi przyglądało się ponad sto tysięcy kibiców. Do ostatniej przebudowy, modernizowano skocznię osiemnascie razy. Od malej, na ktorej skoczkowie zaliczali kilkanaście metrów w XIX wieku do oświetlonej budowli, na której zawodnicy skakali po $140 \mathrm{~m}$. Podobnie jak w Innsbrucku wzgórze, na którym położona jest skocznia jest na tyle niska, ze w pewnym momencie zaczęto wkopywac się w głą góry by można było oddawać dalsze skoki. Tak nadsypan część góry, gdzie powstało muzeum narciarstwa a poniżej mination conditions. The white, semi-translucent
structure outlines its wavy shape against the background of the snow and sky. The sunlight that appears on the white panels and the shaded places After sunset, artificial light illuminating the massa sculpture visible from the entire city $y^{31}$.

The three levels of the tower can be accessed by an When there is no competition ort trainin 332 step being held at the ski jumping hill, tourists can scale the entirety ofthe tower and take in the view of the no restaurant at the top like in Innsbruck. It is instead located near the spectator stands. It is larger The pre-war spectator stands are currently bein modernised. Modern seats are currently being inous spaces meant for tourists (a shop, a museum). as well as the Garmisch-Partenkirchen skiing club. One interesting solution is the shaping of the jump of the tracks and the maintennance of a snow cap
ondun on the jumping section only require a minimum amount of energy. The plastic surface makes
possible for the ski jumping hill to be used in the The final example to be described is the Holmenkollen ${ }^{32}$ ski jumping hill in Oslo, built in 2010 acchitects. The first ski jumping hill, Husebybakken, was built
here in 1879 and was replaced by Holmenkolbakken in 1892. In 1952 the structure hosted competitors during the VI Winter Olympic Games.
was then that permanent spectator stands were built here and the competition was watched by over one hundred thousand spectators. Until the
most recent remodelling, the ski jumping hill was most recent remodelling, the ski jumping hill was
modernised eighteen times. From a small hill, on which jumpers would score distances of around a dozen metres in the nineteenth century, to a fully
illuminated structure on which competitors have illuminated structure on which competitors have
reached distances of around $140 \mathrm{~m}$. Similarly as in Innsbruck, the hill on which the facility is located is low enough that past a certain point it was only
possible to dig inside the mountain in order to pro- 


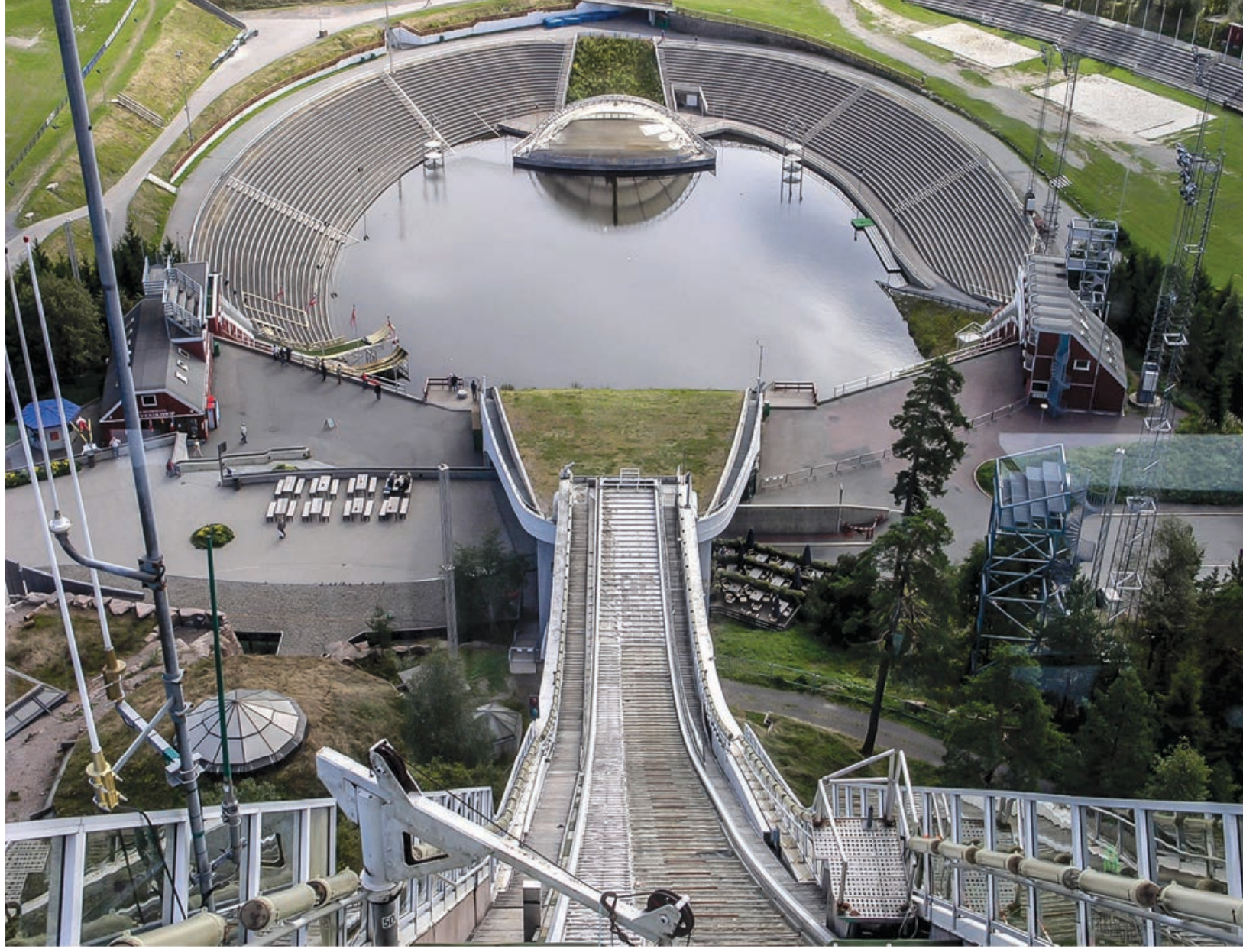

II. 13. Skocznia Holmentollen w Oslo, konkurs skoków podczas VI Zimowych lgrzysk Olimpiiskich w 1952 roku, źródto: www.matkaopas.info/oslo/, dostepp: 20.08.2018
III.13. The Holmenonon ski jumping hill in Oslo, ski jumping copetition during the VI Winter Olympic Games in 1952, source: www.matkaopas.
info/oslo/, acess: 20.08.2018

powstała niecka do której wlatują skoczkowie i po lądowaniu wyjezdzają z niej po przeciwstoku. Jedynym w swoim rodzaju było rozwiązanie, kiedy w lecie wypełniano nieckę wodą. Turyści i mieszkańcy przychodzili tu kąpać się jak na normalnym basenie. Adam Małysz zapisał tu swoją historię będąc jedynym skoczkiem, który wygrał tu zawody Pucharu Świata pięć razy

Decyzja o budowie nowej skoczni powstała w 2005 roku. Ogłoszono międzynarodowy konkurs architektoniczny. Wygrała go pracownia JDS / Julien De Smedt Architects. Architekci zabudowali zeskok konstrukcją stalowa w której schowano pomieszczenia dla sędziów oraz pokoje techniczne. Stalowa konstrukcja kontynuuje swoja droge ku niebu stajac sie pochylona wieża Skocznia od zawsze była punktem orientacyjnym w panoramie Oslo. Jednak teraz stała sie ikom miasta. Zrealizowany projekt jest tak wyjątkowy, że skocznia

vide the ability to score longer jumps. In addition, for a skiing mouseum, while a recess was formed below it-serving as the place where jumpers land and lose speed and leave it using the backslope. The solution of having the entire space filled up
with water during the summer is one of a kind Tourists and residents came here to bathe like in a normal pool. Adam Malysz made history here, becoming the only athlete who won five World Cup

The decision to build a third ski jumping hill was
made in 2005. An interntection petition was organised. It was won by the JDS / Julien de Smedt Archicects company. The architects surrounded the jumping section with a steel struc-
ture in which they hid spaces for judges and technical facilities. The steel structure continues into the sky, transforming into a tilted tower. The ski jumpthe Oslo panorama. However, it now became an

II. 14. Skocznia Holmenkollen w Oslo, projekt zagospodarowania terenu i przekrój, źródto: www.archdaily.com/67931/new-holmenkolle -beacon-jds
III. 14. The Holmenkollen ski jumping hill in Oslo, site development plan and cross-section, source: www.archdaily.com/67931/new-holmenkollen-
-beacon-jds
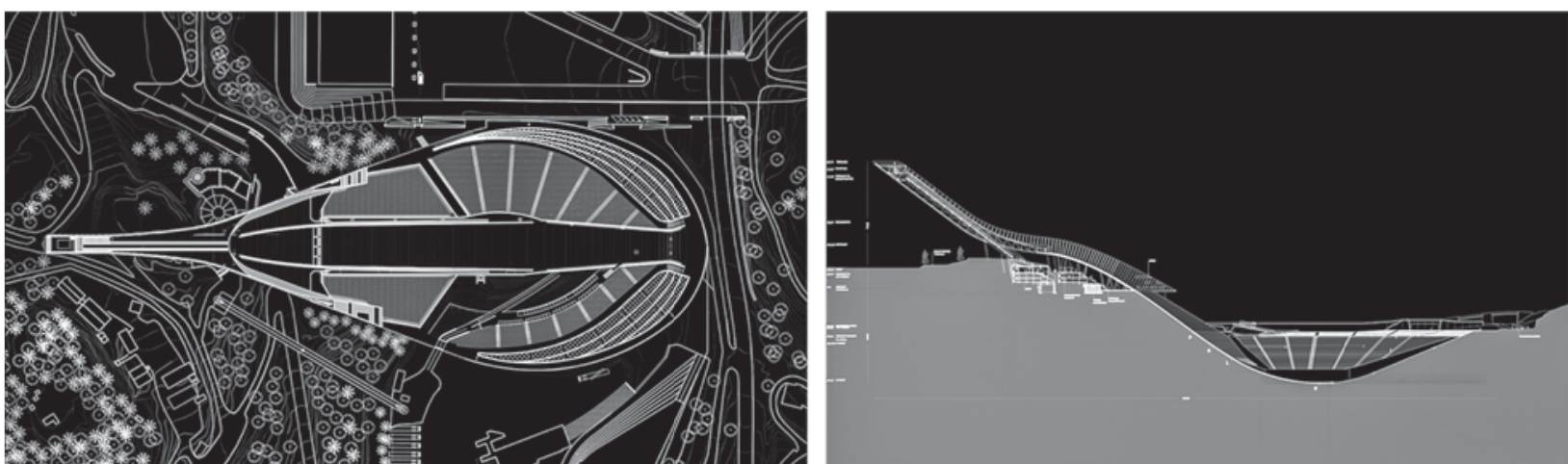

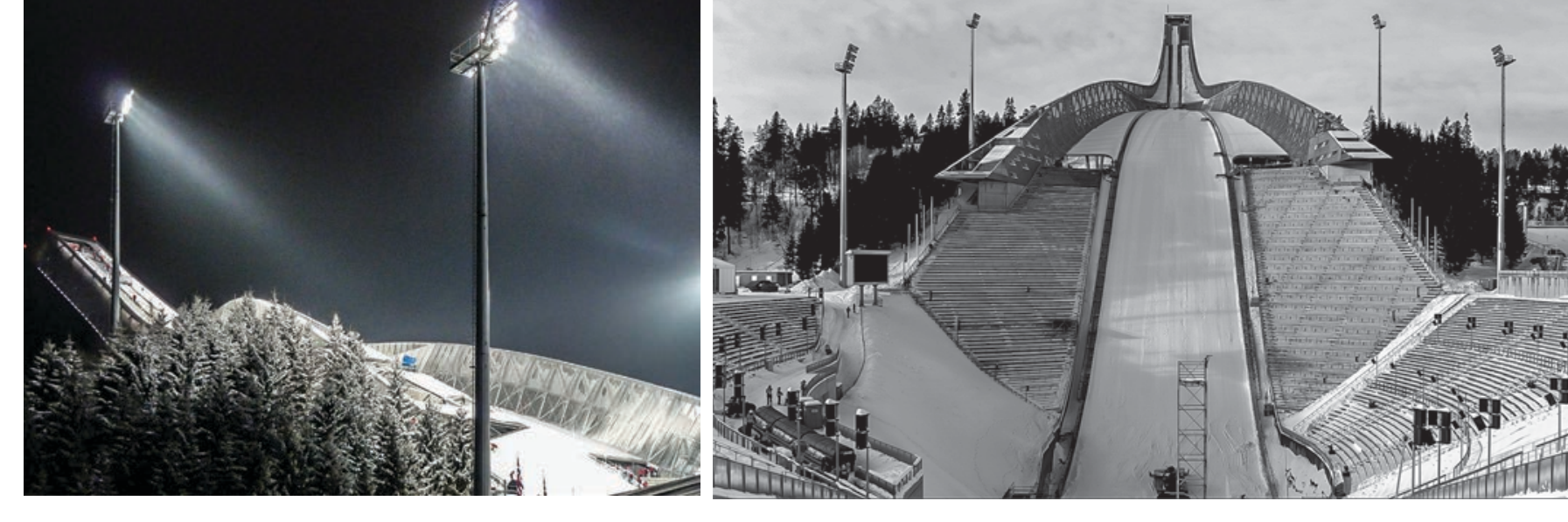

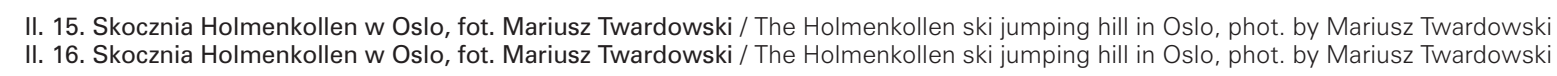

stała się najczęściej odwiedzanym miejscem przez turystów przybywaiacych do Oslo 34

Ulotny kształt wieży, której elewacje zostały wykonane z siatki stalowej sprawiaja, że budowla delikatnie unosi się ponad wzgórzem Holmenkollen. Konstrukcja stalowa wykonana jest $w$ formie kratownicy a jej ostre krawędzie dynamizuja sylwetkę. 35 Użycie nowoczesnych materiałów nie oznacza ze projektanci nie uszanowali tradycji, widoków i panoramy miasta. I tak należy czytać tę formę: $z$ daleka jako ikonę w panoramie miasta, z bliska, jako dynamiczną i nowoczesną formę wpisaną w górę Holmenkollen i ze szczytu wieży, $z$ tarasu widokowego $z$ widokiem na miasto i otaczające fiordy $y^{36}$. Na szczyt wiezy skoczkowie dostac się mogą windą i po schodach pnących się po skosie wiezy. Stopnie są osłonięte stalową siatką. Idąc można oglądać otaczający świat poniżej. Siatka stalowa staje się również ochroną przeciwwiatrowa, choć skoczkowie narzekaja, że zatrzymuje ona nieco zby dużo wiatru i bywa, że nad zeskokiem tworzą się niewielkie wiry ${ }^{37}$. Rozbudowano również trybuny, które mieszcza obecnie 30 tysięcy miejsc.

Ze względu na wyjątkowe miejsce na mapie Oslo i popularność wśród turystów ${ }^{38}$, przy skoczni znajduje sie niewielka nesc ha hotelowa kilkanácie restauracii i kawiarni, komplek baza ho od tury sompleks (rozbucow, pole golowe, muzeum niciastwa i skepik z panoras na Oslo i otaczajace fiordy do skoczni wybudozanoramą na Oslo i

$Z$ fiordu, podświetlona skocznia sprawia wrażenie nowoczesnej latarni morskiej, dzięki której marynarze wracający do Oslo bezpiecznie trafią do swoich domów.

\section{Podsumowanie}

Wydaje się, że te trzy skocznie są wyjątkowymi przykładami nowoczesnych rozwiązań budowli sportowych. Ich wyjątkowość związana jest również w trudnością funkcjonalna. Wszyscy projektanci w taki sposób rozwiązywali architekturę, by nie sluzyla one jedynie kikudziesięciu osobom raz w roku ale zwiedzającym przez wszystkie pozostale dni w roku. Bardzo istotnym elementem jest indywidualność architektoniczna ięekno samej budowli. Każda z nich stała się ikoną swojego miasta, punktem orientacyjnym a zarazem rzeźbą, którą będąc w danym mieście nalezy zwiedzic i oglądnąc. Zachwycaja icon of the city. The built project is so exceptional
that the ski jumping hill became the most-visited

The fleeting shape of the tower, whose facades to appear to lightly levitate above the Holmenkollen hill. The steel structure in the form of a truss and its sharp edges dynamise its outline ${ }^{35}$. The use modern materials does not mean that the depanorama of the city. This is how this form should be read: from afar as an icon within the panorama of the city. From up close, as a dynamic and modand from the top of the tower, from thountain vation terrace, with a view of the city and its surrounding fjords ${ }^{36}$. We can get to the top of the towtilt of the tower. The stairs whe shich climb along the net. When walking we can look at the world below. The steel net also plays the role of protecting against wind, but jumpers have complained tha blocks slightly too much wind and sometimes The spectator stands have also been expanded, currently having a capacity of 30 thousand seats. Due to its exceptional place on the map of Oslo feature a small hotel base, around a dozen restaurants, a biathlon complex, a golf field, a skiing museum, a shop (expanded during the aforemenat the top of the tower there is an obser, whition deck with a panorama of Oslo and the surrounding fjords. An underground railway station has been provided for the ski jumping hillsy.

When seen from the fjord, the ski jumping hill apailors returning to Oslo can safely return to their homes.

4. Conclusion

th appears that these three ski jumping hills are an exceptional example of modern solutions in sports facilities. Their extraordinary character is
also associated with functional difficulties. All of ner that would not serve merely several dozen people once a year, but that would also cater to visitors throughout the remaining days of the
year. Architectural individuality and the beauty of the structures are highly essential elements. They have all become icons of their respective cities, an orientation point and at the same time a sculpture city where they are located. They impress us with their shape and delicateness. They do not domi- 
17 Queralbs Caralps [W: S Skocznie narciarskie, www.skisprungschan-
zen.com/PL/Skocznie/SPA-Hiszpania//Queralbs/0098-N\%C3\%BAria/
(dostep. 02062018 r) is San Carlos de Bariloche [W:] Skocznie narciarskie, http://
www.skisprungschanzen.com/PL/Skocznie/ARG-Argentyna/ WWw. skisprungschanzen.com/PL/Skocznie/ARG-Argentyna/

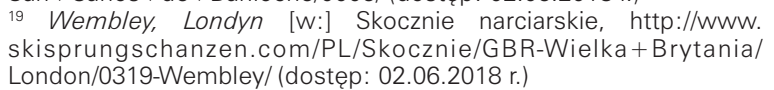
${ }_{20}$ A Ski Jump On Hampstead Heath [W:I Londonist, 11.12.2017, https:///ondonist.com/2014/02/a-ski-jump-on-hampstead-heath
(dostepp: 02.06.2018 r.) 1dostep: 02.06.2018 r.)
21 Mark Langill, The Dodger Stadium ski jump [W:] Dodgers Insider,
21.01 .2014 , https://dodgers.milblogs.com/the-dodger-stadium-ski-

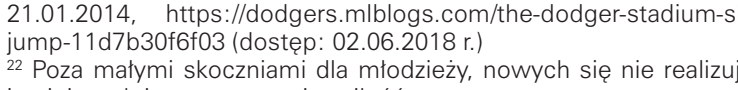

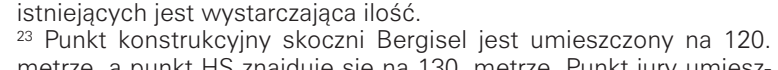
metrze, a punkt HS znajduje sie na 130 . metrze. Punkt jury umiesz-
czony jest na 134 . metrze. Obiekt ten nie jest wyposazony $w$ szzuczne oświetlenie, które bytoby potrzebne przy rozgrywaniu konkursów we
${ }_{24}$ Turniej

i Garmisch-Partenkirchen w Niemczech oraz w Innsbrucku i i Bischofshofen w Austrii. Konkursy gromadza niewiarygodna ilość widzów.
25 Luke Fiederer, AD Classics: Bergise/ Ski Jump / Zaha Hadid Afchitects [w:I Arch Daily, 09.05.2016, www.archdaily.com/786967/
ad-classics-bergisel-ski-jump-zaha-hadid-architects-innsbruck-austrial (dostepp: 03.06.2018 r.
26
26

(W:I Zaha Hadid Architects, www.zaha-hadid. 32 Reprezentant Polski, brazowy medaslist? 0.06 .2016 . 27 Reprezentant Polski, brazowy medalista olimpiiski, skoczek nar-
ciarski Dawid Kubacki w specjalanej rozmowie z autorem tekstu na temat trzech opisywanych skoczni, Kraków, czerwiec 2017 r.
${ }_{28}$ Za: Dawid Kubacki w specjalnej rozmowie z autorem tekstu na temat trzech opisywanych skoczni, Kraków, czerwiec 2017 r.
${ }_{20}$ Za: Dawid Kubacki w specjalnej rozmowie z autorem tekstu na temat trzech opisywanych skoczni, Kraków, czerwiec 2017 r.
${ }_{30}$ OSS Ski Jump Garmisch Partenkirchen [w: terrain. integral designs, http://terrain.de/oss-ski-jump-garmisch-partenkirchen/ (dostep: 09.06.2018 r.)
31 New Olympic Ski

in New Olympic Ski Jump in Garmisch-Partenkirchen I terra-
in: loenhartymayr [W:] ArchDaily. 30.12.2008, www.archdaily. irchen-ter32 Petha nazwa skoczni to Holmenkollbakken, za Holmenkollen [w:]
Holmenkollen, Oslo, https://www.skiforeningen.no/holmenkollen/ Holmenkollen, OSlo,
(dostęp: 11.06.2018.)

(dostep: 11.06.2018 r.)
33 Okrzykniety zostat ,królem Holmenkollen" in nagrodzony zostat
medalem Holmenkollen. Za: Grzegorz Wojnarowski, To on wymys lit medalem Holmenkollen. Za: Grzegorz Wojnarowski, To on wymyst
"króla Adama". Scheie: pieć zwyciesstw Matysza w Oslo robi wra

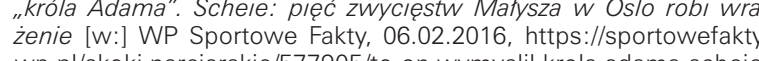
wp. pl/skoki-narciarskie/577905/to-on-wymyslil-krola-adama-scheie-
-piec-zwyciestw-malysza-w-oslo-robi-wrazenie (dostęp: 12.04.2018 ${ }_{34}^{r .)}$ Najpiękniejsza skocznia narciarska świata - Holmenkollibakken w Os/o [W: A Archirama, https:///archirama. muratorplus.pl/architektu-
ra/najieiekniejsz-skocznia-narciarska-swiata-holmenkollibakken-w-oslo,67 1290. html\# (dostep: 15.09.2017 r.)
35 HOP T Holmenkollen Ski Jump [W:] JDS, http:///dsa.eu/hop/ (do35
step: 15.09.2017 r.) step: 15.09.2017 r.)
36 New Holmenkollen Beacon I JDS [W:] ArchDaily, 09.07.2010,
www.archdaily.com/67931/new-holmenkollen-beacon-jds (dostepp: 10.03.2018 r.) temat trzech opisywany ch skoczni, Kraków, czerwiec 2017 r.
38 Lonely Planet uznato, że skocznia jest jednym z naibardziej atrak-

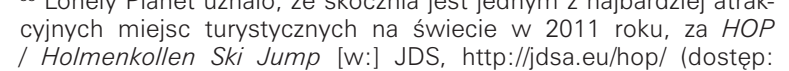
, htps:/mmw skiforen 39 Holmenkollen [W:] Holmenkollen, Oslo,
gen.nol/holmenkollen//(dostẹp: 11.06.2018 r.

\section{LITERATURA}

[1] A Ski Jump On Hampstead Heath [w:] Londonist, 11.12.2017, https:///londonist.com/2014/02/a-ski-jump-on-hampstead-heath
[2] Bergise/ Ski Jump [w:] Zaha Hadid Architects, www.zaha-hadid.

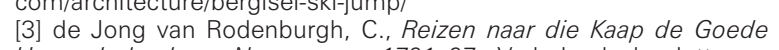

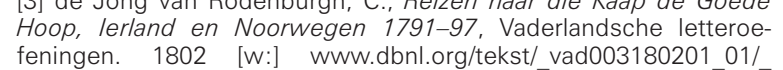

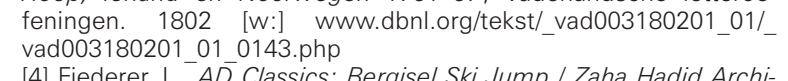

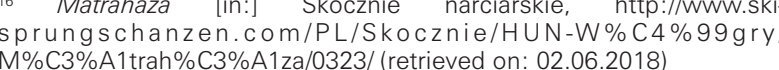
17 Queralbs Caralss lin:I Skocznie narciarskie, ww. wkisprungschanzen.
com/PLLSkocznie/SPA-Hiszpania/Queralbs/O098-N\%C3\%BArial (retrieved on: 02.06.2018)
18 SWh. 18 San Carlos de Bariloche [in:] Skocznie narciarskie, http://
www. skisprungschanzen.com/PL/Skocznie /ARG-Argentyna/
San+Carlostde+Bariloche/0006/(retrieved on: 02.06.2018)

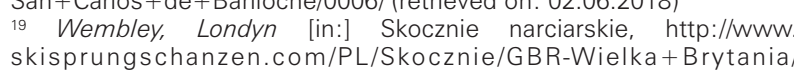
skisprungschanzen. com/PL/Skocznie/GBR-Wielka + Brytania
London/0319-Wembley/(retrieved on: 02.06.2018)

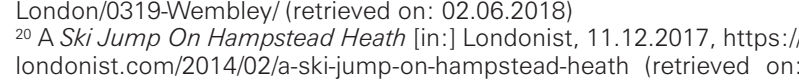
Iondonist.com/2014/02/a-ski-jump-on-hampstead-heath (retrieved on:
02.06 .2018 ) ${ }^{21}$ Mark Langill, The Dodger Stadium ski jump lin:l Dodgers Insider
21.01 .2014 https://dodgers.mllblogs.com/the-dodger-stadium-ski-jump-11 d7b30fffo3 (retrieved on: 02.06.2018) 22 Apart from small ski jumping hills for the youth, new ones are no
being built, with existing ones seen as sufficient. ${ }_{23}^{23}$ The construction point of the Bergisel ski jumping hill is set at the

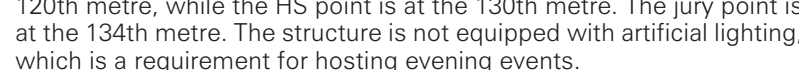
${ }^{24}$ The tournament is organised each year at facilities in Obersdorf and fen in Austria. The competitions attract an unbelievable amount
for 25 Luke Fiederer, AD Classics: Bergisel Ski Jump / Zaha Hadid Architects

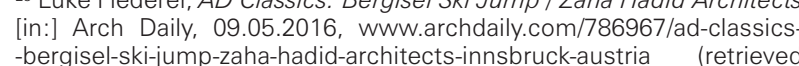
-bergisel-ski-jump-zaha-hadid-architects-innsbruck-austria (retrieved
on: 03.06.2018)
26 Bergisel SKi Jump lin. I Zaha Hadid Architects, wmw zaha-hadid com

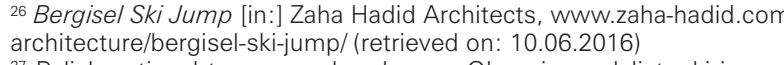
${ }^{27}$ Polish national team member, bronze Olympic medalist, ski jumper
Dawid Kubacki in a special inview with the author of the text on the subject of the three ski jumping hills, Krakow, June 2017. ${ }^{28}$ From. Dawid Kubacki in a special interview with the author of the tex
on the subject of the three ski jumping hills. Krakow J Jne 2017 29 From: Dawid Kubacki in a special intervivew with the author of the text
on the subject of the three ski jumping hills, Krakow, June 2017 .

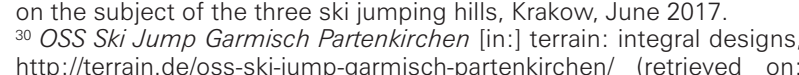

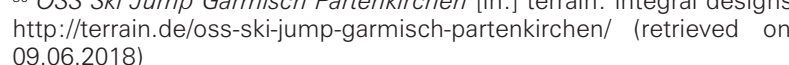
09.06.2018)
31. New Olympic Ski Jump in Garmisch-Partenkirchen / terrain.
loenhartfrmayr [in:] ArchDaily, 30.12.2008, www.archdaily.com/10969 new-olympic-ski-jump-in-garmisch-partenkirchen-terrain-loenhartma ${ }^{32}$ The full name of the facility is Holmenkollbakken, from Holmenkollen
lin:] Holmenkollen, Oslo, https://www.skiforeningen.no/holmenkollen [in:] Holmenkollen, Oslo,
(retrieved ons: 11.06 .2018 )
3ntilww.skiforeningen.no/holmenkollen/ menkollen medal. From: Grzegorz Woinarowski, To on wymyslit , kró

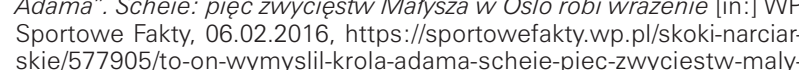
skie//577905/to-on-wymy sili-krola-adama-scheie-piec-zwyciestw-maly
sza-w-oslo-robi-wrazenie (retrieved on: 12.04.2018) Sza-W-oslo-robi-wrazenie (retrieved on: 12.04.2018)
${ }_{33}$ Najpiegkniejzza skocznia narciarska swiata - Holmenkollbakken w Oslo [in:] Archirama, https:///archirama.muratororlus.pl/architektura/najpiek-
niejszz-skocznia-narciarska-swiata-holmenkollbakken-W-oslo,67_1290.

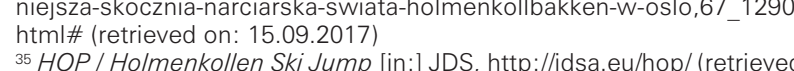
${ }_{35} \mathrm{HOP}$ P / Holmenkollen Ski Jump [in:] JDS, http://jdsa.eu/hop/ (retrieved
on: 15.09.2017)

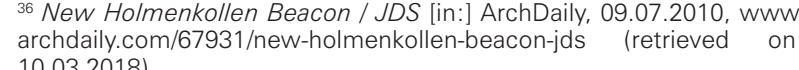
$10.03 .2018)$
37 From: Dawid Kubacki in a special interview with the author of the tex on the subject of the three ski jumping hills, Krakow, June 2017.
${ }_{38}$ Lonely Planet proclaimed the ski jumping hill to be one of the mos attractive tourist destinations in the world in 2011, from HOP / Holmen-
kollen Ski Jump [in:] JDS, http://jsa.eulhop/ /retrieved on: 15.09.2017) 39 Holmenkollen nin: Holmenkollen, Os slo, https: / /Www.skiforeningen
nolholmenkollen/(retrieved on: 11.06.2018)

\section{BIBLIOGRAPHY}

1) A Ski Jump On Hampstead Heath [in:] Londonist, 11.12.2017, https: [2] Bergise/ Ski Jump [in:] Zaha Hadid Architects, www.zaha-hadid.com/ [3] de Jong van Rodenburgh, C., Reizen naar die Kaap de Goede Hoop, ler-

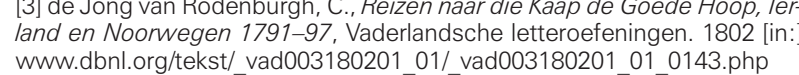

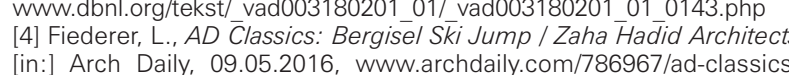

tects I. I. Arch Daily, 09.05.2016, www.archdally.com/786967/ad-clas[5] Historia skoczni narciarskich w Polsce [w:] Skocznie narciarskie w Polsce, https://sites.google.com/site/skocznienarciarskiewpolsce/

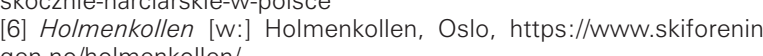
gen.no/holmenkollen/ Holmenkollen, Oslo, https://www.skiforenin [7] Holmenkollen [w,

[8. HOP / Holmennenoll/en Ski Jump [W:] JDS, http:///dsa.eu/hop
[9] Kapeniak, J., Tatranískie diabty, Warszawa 1971

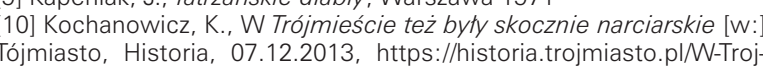
miescie-tei-bylly-skocznie-narciarskie-n75140.html
[11] Langill, M., The Dodger Stadium $k$ ki jump [w:] Dodgers Insider

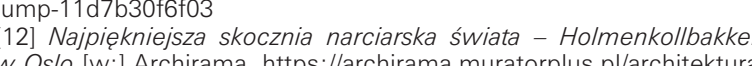
w Oslo [w:] A Archirama, https:///rchirama.muratorplus.pl//architektura
najpiekniejsza-skocznia-narciarska-swiata-holmenkollbakken-w-os 10,67 $1290 . h$ html\#
$[13]$ New Holmentoly

Deacon / JDS [w:] ArchDaily, 0907.2010 Www.archdaily.com/67931/new-holmenkollen-beacon-jds
14] New Olympic Ski Jump in Garmisch-Partenkirchen / terrain: Ioen

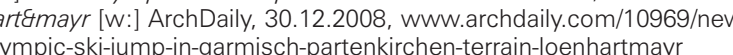
[15] OSS Ski Jump Garmisch Partenkirchen n W:] terrain: integral de

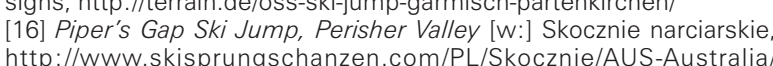
http://WwW.skisprungschanzen.com/PL/Skocznie/AUS-Australia/
NSW-Nowa+Po\%C5\%82udniowa+Walia/Perisher+Valley/1574/ [17] Skocznie narciarskie [ [W. S Skocznie narciarskie, http./Wmws sprungschanzen.com/PL/Skocznie
[18] Soldier Field History: Ski Jump Tournament [w:] Fleet Feet Sports, (18) Soldier Field History: Ski Jump Tournament I W: Fleet Feet Sports.
www.fleetfeetchicago. com/news/soldier-field-history-ski-jumping [19] Szatkowski, W.S Skocznia w Dolinie Jaworzynki - poprzedniczka skie, https:///-ne. pl/s,doc, 23249,1,1728, ...html [20] Wasoouska, M., Historia skokokw narciarskich [w:] SkiJumping.pl,

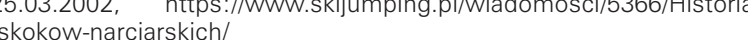

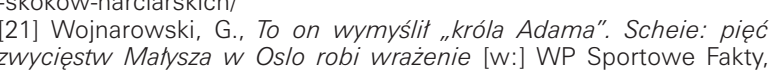
06.02.2016 https://sportowefakty.wp.pl/skoki-narciarskie/57790 to-on-wymysl-
-robi-wrazenie -bergisel-ski-iump-zaha-hadid-architects-innsbruck-austria
[5] Historia skoczni narciarskich $w$ Polsce lin:] Skocznie narciarskie

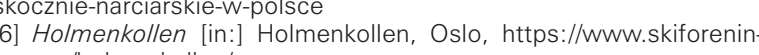
Holmenkollen [in:] Holmenkollen. Oslo, https:// [1] wuw.skiforeningen.no/holmenkollen/ H] HOP/ Holmenkollen Ski Jump [in:] JDS, http://jidsa.eu/hop/

[8] Kapeniak, J., Tatrzańskie diably, W.arszawa a 971 .

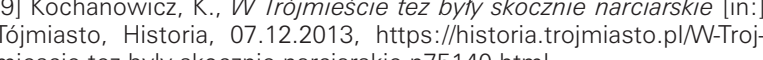
10] Langili, M., The Dodger Stadium ski jump [in:] Dodgers Insider

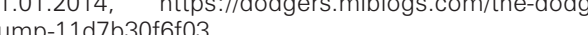
[11] Najpieienniejsza skocznia narciarska świata - Holmenkollbakken w
Oslo [in:] Archirama htps:/larchirama muratorplus. plarchitektura najpiekniejsza-skocznia-narciarska-swiata-holmenkollbakken-w-os12] New Holmenkollen Beacon / JDS [in:] ArchDaily, 09.07.2010, 13] New Olympic Ski Jump in Garmisch-Partenkirch

benhart\&mayr lin:] ArchDaily, 30.12.2008, www.archdaily.com/1096 mayr 14 OSS Ski Jump Garmisch Partenkirchen [in:] terrain: integral desig ns, http://terrain.deloss-ski-jump-garmisch-partenkirchen/
$[15]$ ] Piper's Gap Ski Jump, Perisher Valley lin:] Skocznie narciarskie, http://Www.skisprungschanzen.com/PL/Skocznie/AUS-Australia/
NSW-Nowa+Po\%C5\%82udniowa+Walia/Perisher+Valley/1574/ 16] Skocznie narciarskie [in:] Skocznie narciarskie, http://www.skiSprrangschanzen.com/PLLSkocnnie
Soldier Field History: Ski Jump Tournament lin:] Fleet Feet Sports, 17] Szatkowski, W., Skocznia w Dolinie Jaworzynki - poprzedniczza

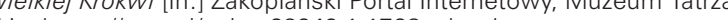

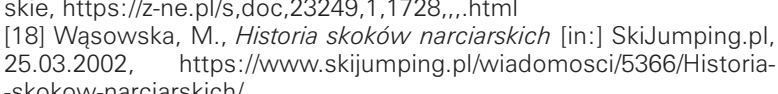

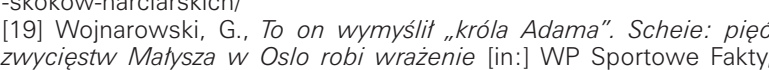
06.02.2016, https:///sportowefakty.wp. pl//skoki-narciarskie/5777905 to-on-wymysli-wrazenie 